Access to this work was provided by the University of Maryland, Baltimore County (UMBC)

ScholarWorks@UMBC digital repository on the Maryland Shared Open Access (MD-SOAR) platform.

Please provide feedback

Please support the ScholarWorks@UMBC repository by emailing scholarworks-group@umbc.edu and telling us what having access to this work means to you and why it's important to you. Thank you. 


\section{Behavioral Systems Management of Confined Microsocieties: An Agenda for Research and Applications}

\section{Henry H. Emurian \& Kip Canfield}

UMBC

Peter G. Roma, Eric D. Gasior, \& Zabecca S. Brinson Institutes for Behavior Resources

Robert D. Hienz, Steven R. Hursh, \& Joseph V. Brady Johns Hopkins University School of Medicine 


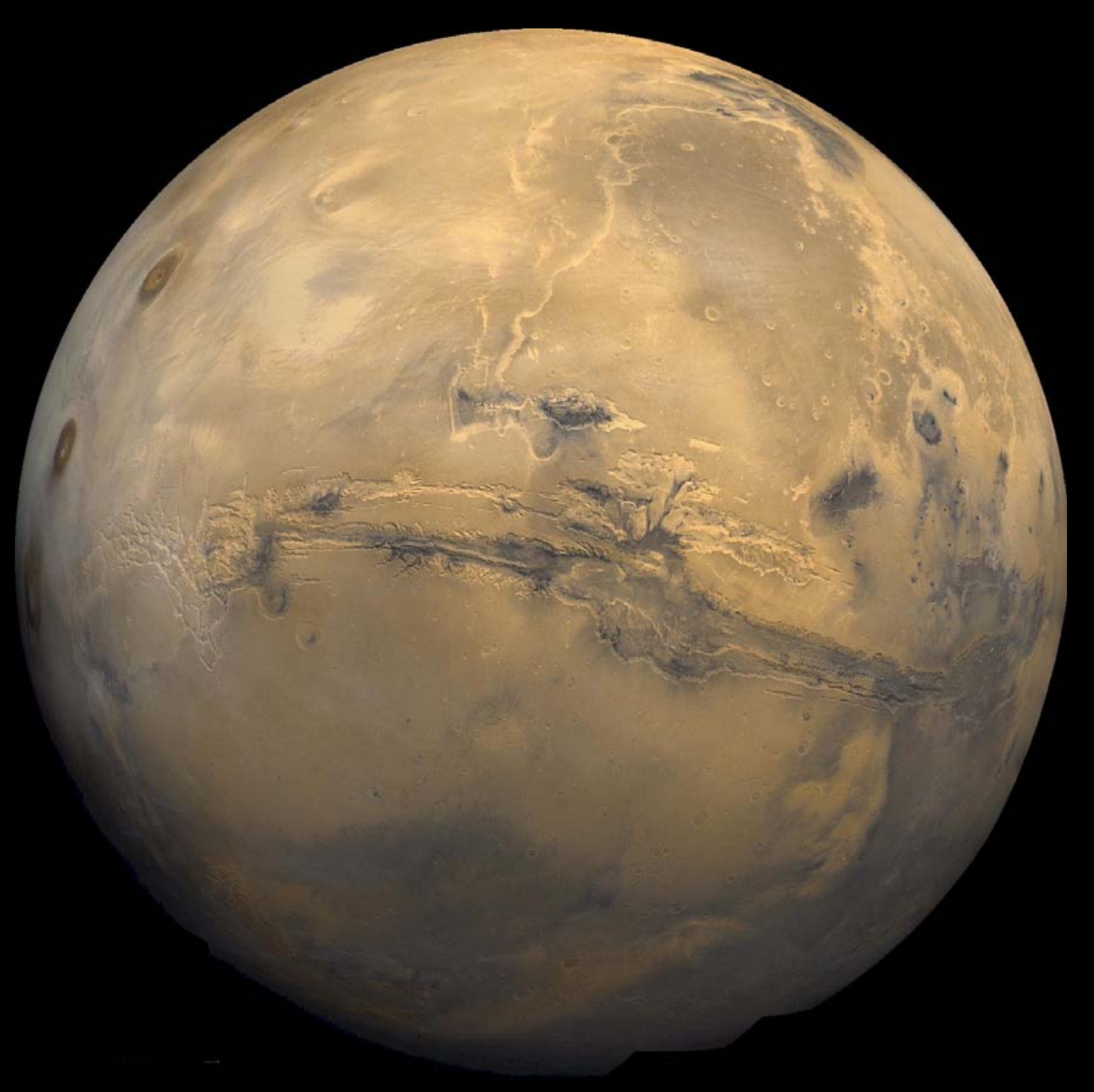

(a) 


\section{$\underline{\text { washingtonpost.com }}>\underline{\text { Columns }}$}

\section{Time to Boldly Go Once More}

By Buzz Aldrin

Thursday, July 16, 2009

Much has been said recently about the Vision for Space Exploration and the future of the international space station. As we all reflect upon our historic lunar journey and the future of the space program, I challenge America's leaders to think boldly and look beyond the moon. Yes, my vision of "Mars for America" requires bold thinking. But as my friend and Gemini crewmate Jim Lovell has noted, our Apollo days were a time when we did bold things in space to achieve leadership. It is time we were bold again in space. 
- Extended stays by human groups in extraterrestrial vehicles and habitats will be common in this century.

- Ensuring participants' behavioral health requires consideration of innovative approaches to microsociety management. 


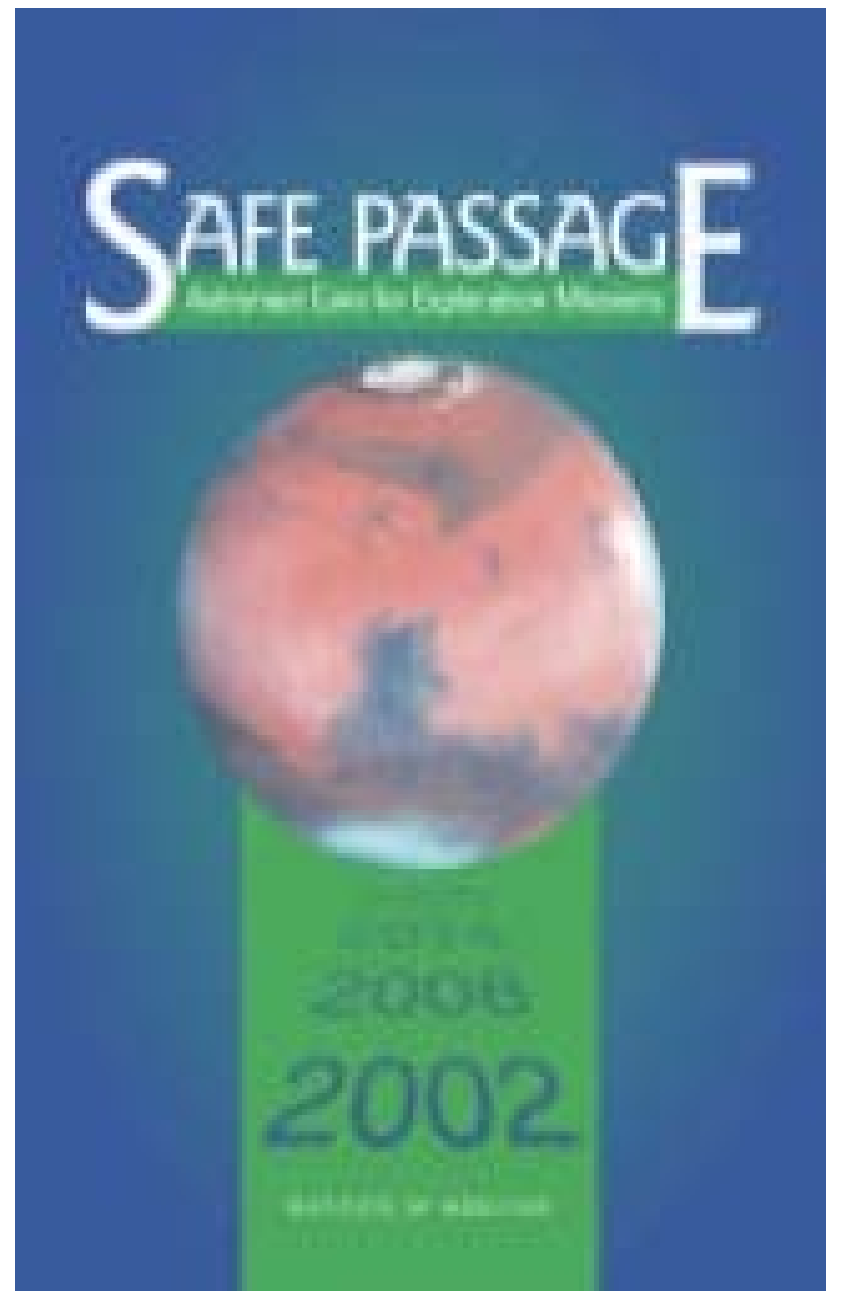

http://books.nap.edu/html/safe passage/reportbrief.pdf 
Aviation, SPACE, AND

ENVIRONMENTAL MÉdicine

New-Directions in Spaceflighte Behavioral Health? A Workshop Integrating Research and Application

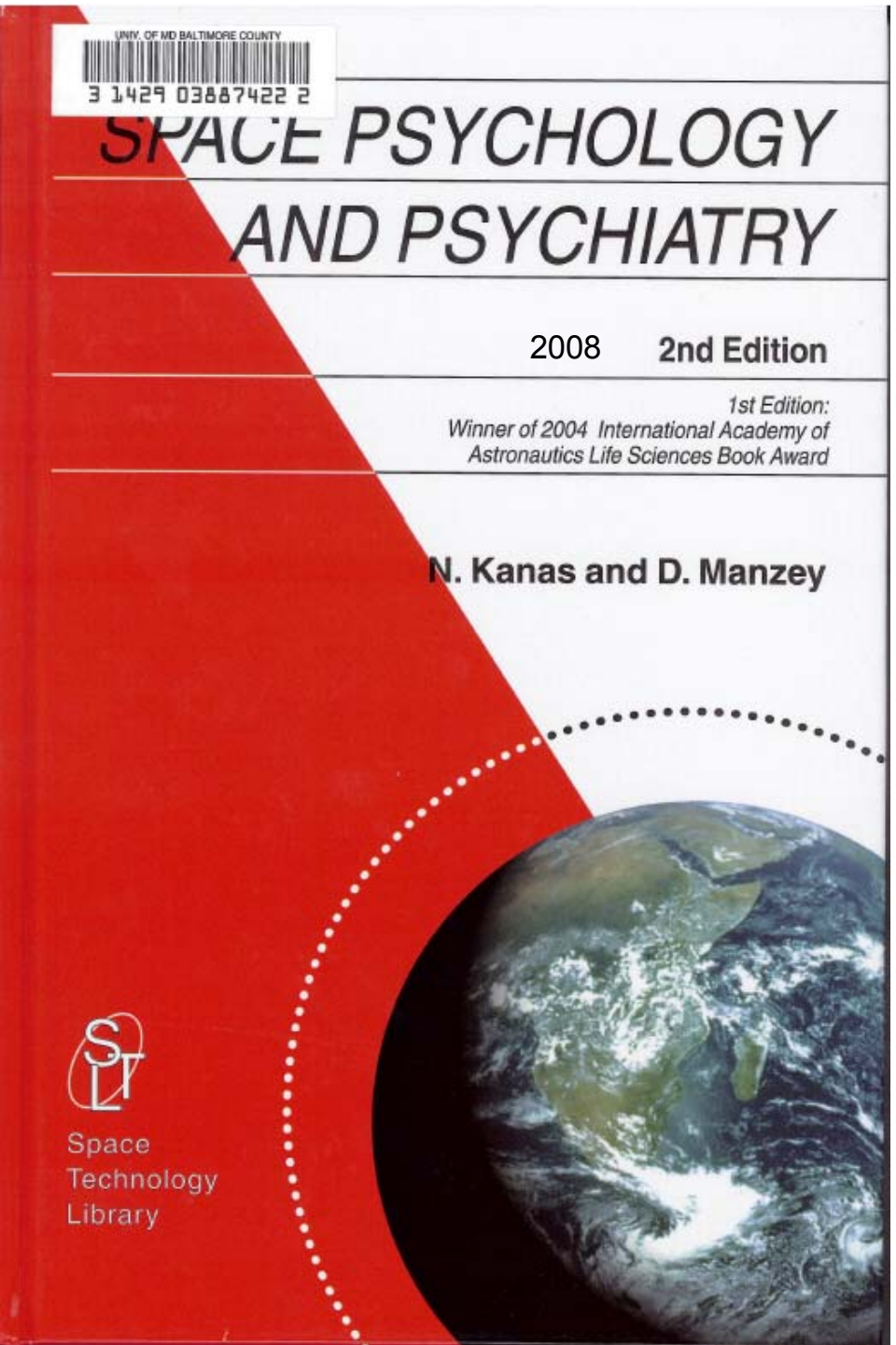



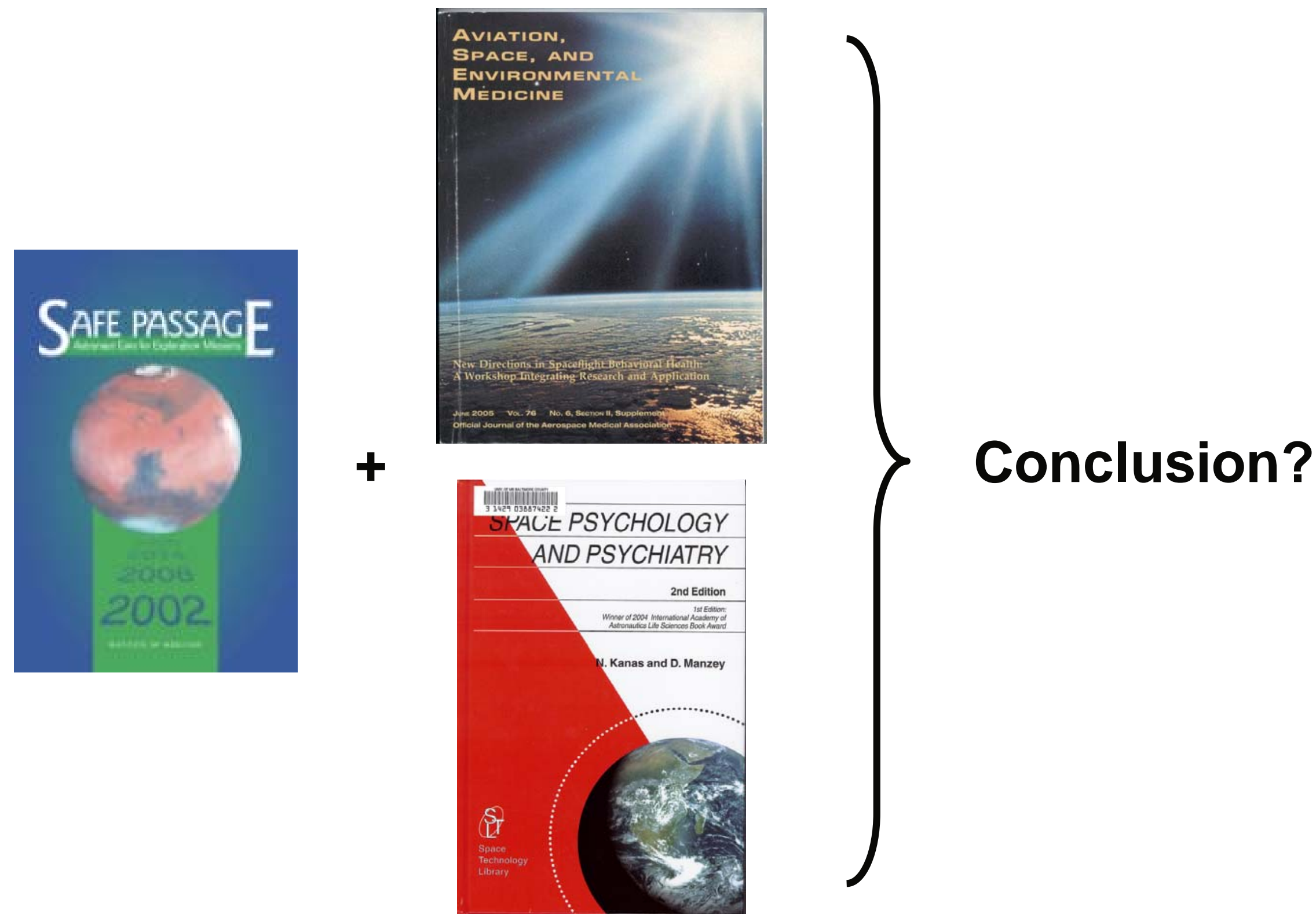


\section{Life in Space Will Not Be Easy}

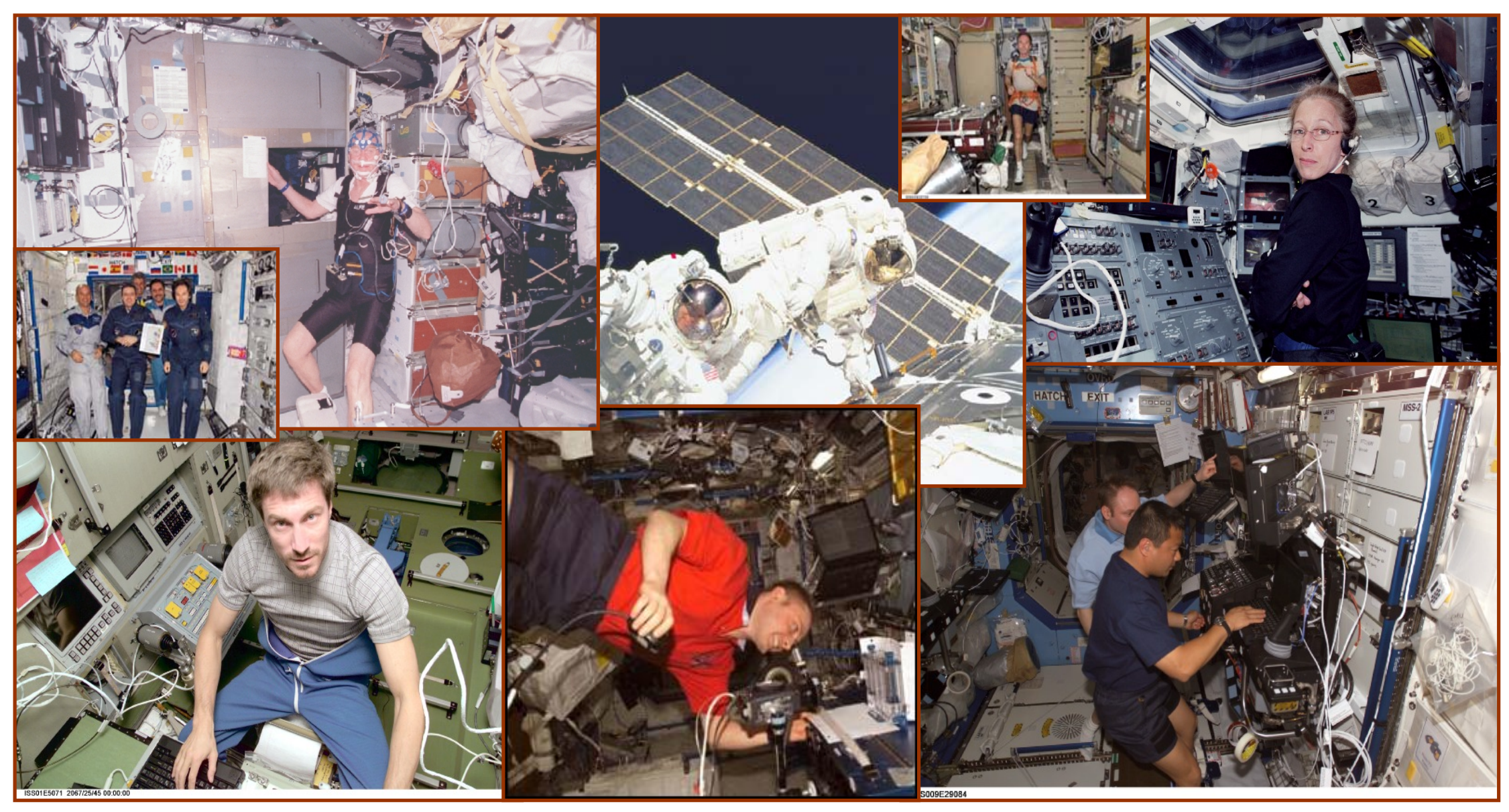


BEHAVIORAL HEALTH REQUIREMENTS-BRADY
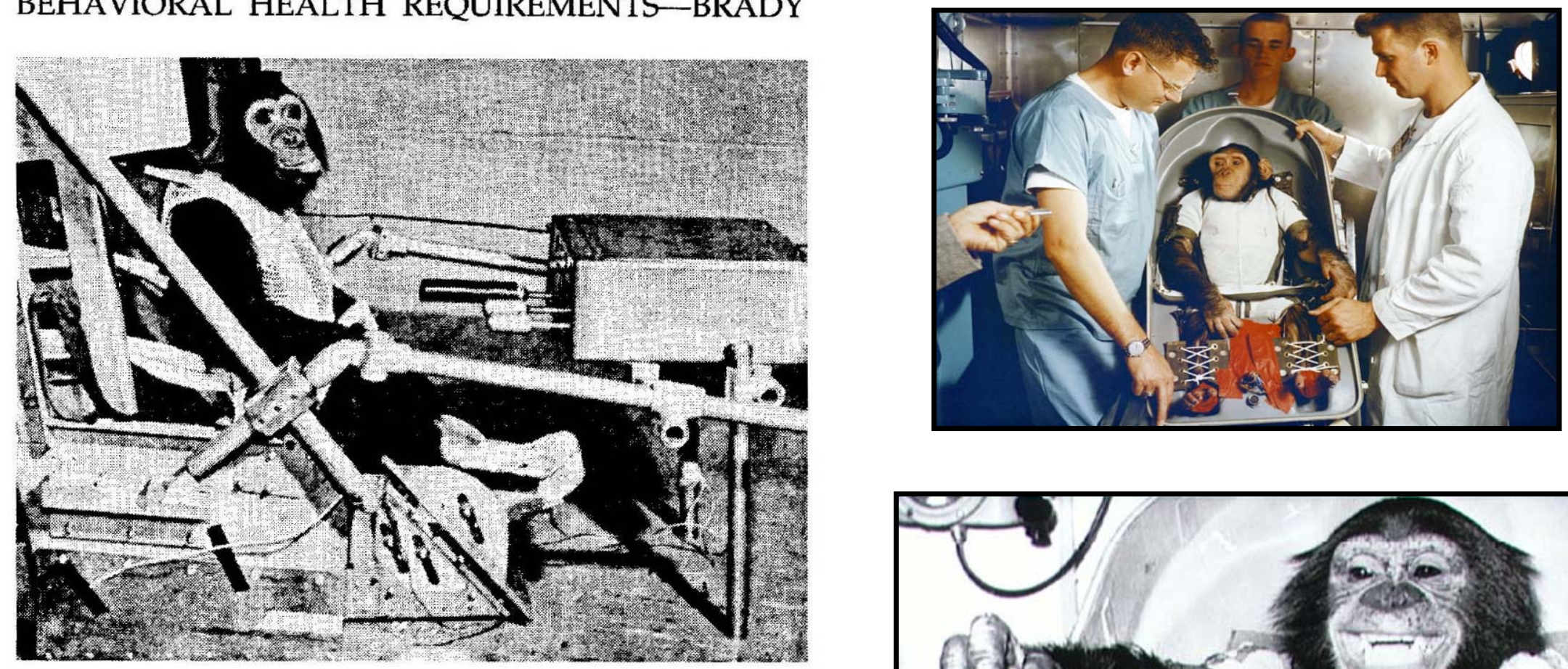

Fig. 4. Chimpanzee training device for animal pretest flights of Project Mercury. Personal collection of the author.
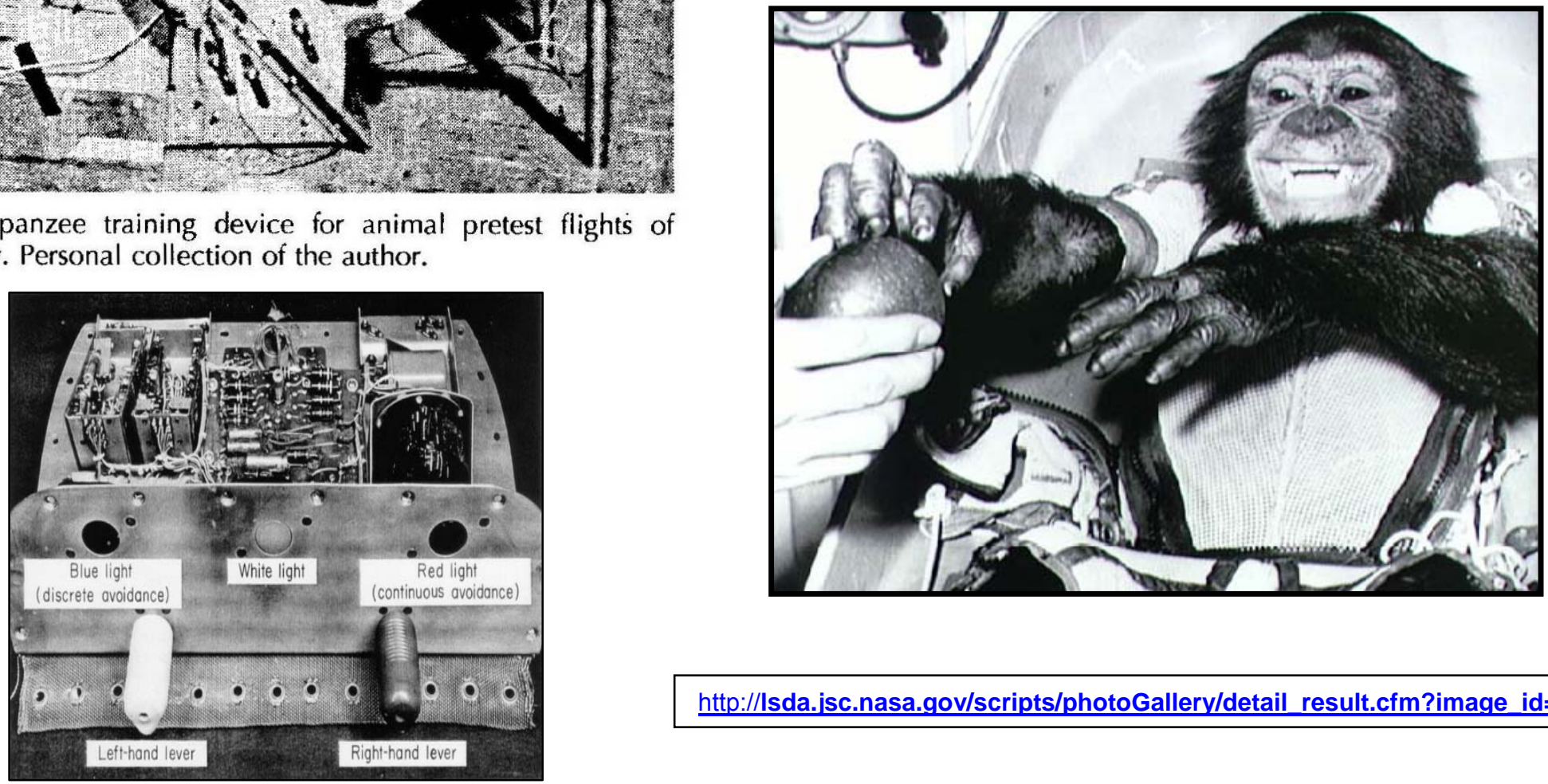

http://lsda.jsc.nasa.gov/scripts/photoGallery/detail result.cfm?image id=1804 


\begin{tabular}{|c|c|c|}
\hline Time & Crew & Ops \\
\hline 06:00-06:10 & $\begin{array}{l}\text { CDR,FE-1,FE- } \\
2, \text { FE-3 }\end{array}$ & Morning inspection \\
\hline 06:00-06:05 & FE-5 & SLEEP - data logging FE5 \\
\hline 06:00-06:05 & FE-4 & SLEEP - data logging FE4 \\
\hline 06:05-06:35 & FE-4,FE-5 & Post-sleep \\
\hline $06: 10-06: 40$ & $\begin{array}{l}\text { CDR,FE-1,FE- } \\
2\end{array}$ & Post-sleep \\
\hline $06: 10-06: 20$ & FE-3 & MO-8. Test config \\
\hline $06: 20-06: 35$ & FE-3 & Body mass measurement \\
\hline $06: 35-06: 50$ & FE-4 & Body mass measurement \\
\hline $06: 35-06: 50$ & FE-5 & Breakfast \\
\hline 06:35-07:05 & FE-3 & Post-sleep \\
\hline $06: 40-07: 30$ & $\begin{array}{l}\text { CDR,FE-1,FE- } \\
2\end{array}$ & Breakfast \\
\hline $06: 50-07: 30$ & FE-4 & Breakfast \\
\hline 06:50-07:05 & FE-5 & Body mass measurement \\
\hline $07: 05-07: 15$ & FE-3 & MO-8. Concluding steps \\
\hline 07:05-07:30 & FE-5 & Breakfast \\
\hline 07:15-08:05 & FE-3 & Breakfast \\
\hline 07:30-07:50 & FE-4 & Nutrition and Repository - urine sample collection \\
\hline 07:50-07:55 & FE-2 & Ham radio HW prep \\
\hline 07:50-08:00 & FE-4 & $\begin{array}{l}\text { Nutrition и Repository - installing first urine samples into } \\
\text { MELFI }\end{array}$ \\
\hline 07:55-08:00 & FE-5 & Nutrition и Repository. Photographing \\
\hline 07:55-08:05 & FE-2 & Ham radio session \\
\hline 08:00-08:20 & FE-4 & Nutrition и Repository - blood sample collection \\
\hline 08:00-08:15 & FE-5 & Nutrition и Repository - blood sampling operator \\
\hline 08:00-08:05 & FE-1 & Nutrition и Repository. Photographing \\
\hline 08:05-08:15 & FE-3 & $\begin{array}{l}\text { Verifying absence of cooling agent on housing of half- } \\
\text { coupling } 4 \text { ГБ } 4 \text { КОБ } 2\end{array}$ \\
\hline $08: 15-09: 15$ & FE-3 & FЕ ВЕЛО - 4 \\
\hline 08:20-08:30 & CDR,FE-1 & Remove Oxygen Unit БК-3 and БРТА battery / ODF \\
\hline 08:20-08:30 & FE-4 & $\begin{array}{l}\text { Nutrition и Repository - assembling cooling centrifuge } \\
\text { equipment }\end{array}$ \\
\hline $08: 20-08: 40$ & FE-5 & Nutrition - urine sample collection \\
\hline
\end{tabular}

\section{"Behavioral Program"}

\begin{tabular}{|c|c|c|}
\hline $15: 30-16: 30$ & CDR & Orlan water tank refill \\
\hline $15: 30-15: 35$ & FE-5 & Nutrition - installing urine sample into MELFI \\
\hline $16: 00-17: 15$ & FE-2 & FE ARED \\
\hline $16: 30-16: 45$ & FE-1 & Post EVA PMC (S-band) \\
\hline $16: 30-17: 00$ & CDR & EVA photos downlink \\
\hline $16: 45-17: 00$ & FE-1 & Food questionnaire \\
\hline 17:00-18:00 & CDR & FE ARED \\
\hline 17:00-18:00 & FE-1 & FE CEVIS \\
\hline $17: 20-18: 20$ & FE-3 & FЕ ЭСПАНДЕР - 1 \\
\hline $17: 40-19: 30$ & FE-2 & 3 min long video of science experiment \\
\hline 17:40-17:55 & FE-4 & PFC (S+Ku-band) \\
\hline 18:00-19:30 & FE-1 & FE ARED \\
\hline 18:20-18:50 & FE-3 & Hygiene \\
\hline 18:40-19:00 & FE-5 & Nutrition - urine sample collection \\
\hline $18: 50-19: 30$ & FE-3 & $\begin{array}{l}\text { COЖ maintenance } \\
\text { БМП fan grille cleaning }\end{array}$ \\
\hline 18:50-19:10 & FE-4 & Nutrition and Repository - urine sample collection \\
\hline 19:00-19:05 & FE-5 & Nutrition - installing urine sample into MELFI \\
\hline 19:10-19:15 & FE-4 & Nutrition и Repository - installing urine sample into MELFI \\
\hline 19:15-19:20 & FE-4 & TVIS CEVIS HRM data transfer to MEC \\
\hline 19:20-19:25 & FE-4 & OCA SSC router reboot \\
\hline 19:25-19:30 & FE-4 & OCA SSC server reboot \\
\hline 19:30-21:30 & . & Pre-sleep (supper, daily food ration, pre-sleep) \\
\hline 21:30-06:00 & . & Sleep \\
\hline
\end{tabular}

\section{Notes:}

1 Window 9 cover opening - crew discretion, Report to MCC

2. Missing links to US ops - see OSTP

\section{http://www.nasa.gov/mission pages/station/timelines/06 2009 tl.html}




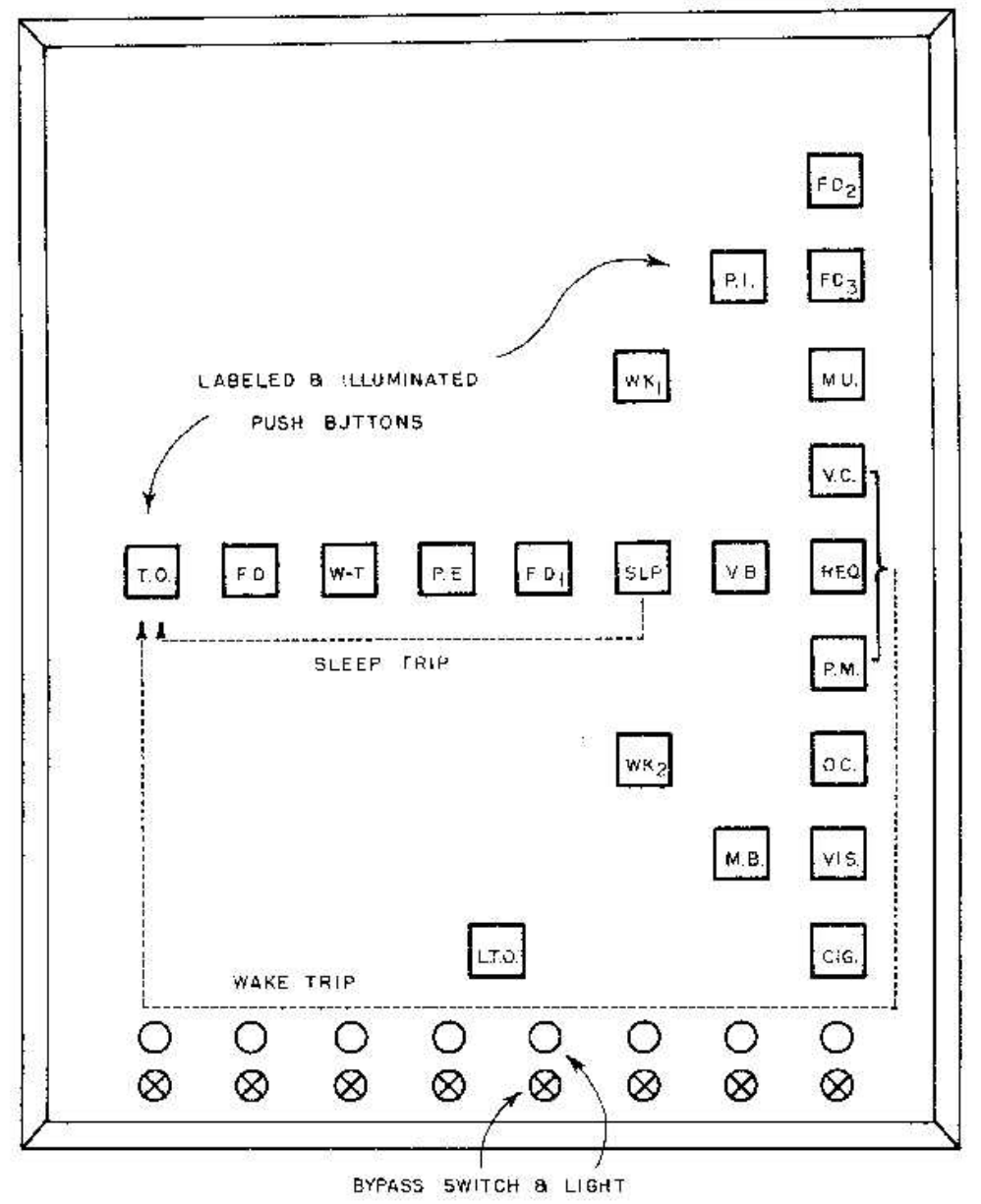

Figure 1. Main control panel containing push buttons that could be illuminated red or green. Each button is labeled with the abbreviations of the activity represented. "Wake Trips" and "Sleep Trips" are indicated by arrows.

Behavioral program supporting a single resident of a programmed environment for 152 days. The multi-operant features are determined by activity alternatives at the transition points. 


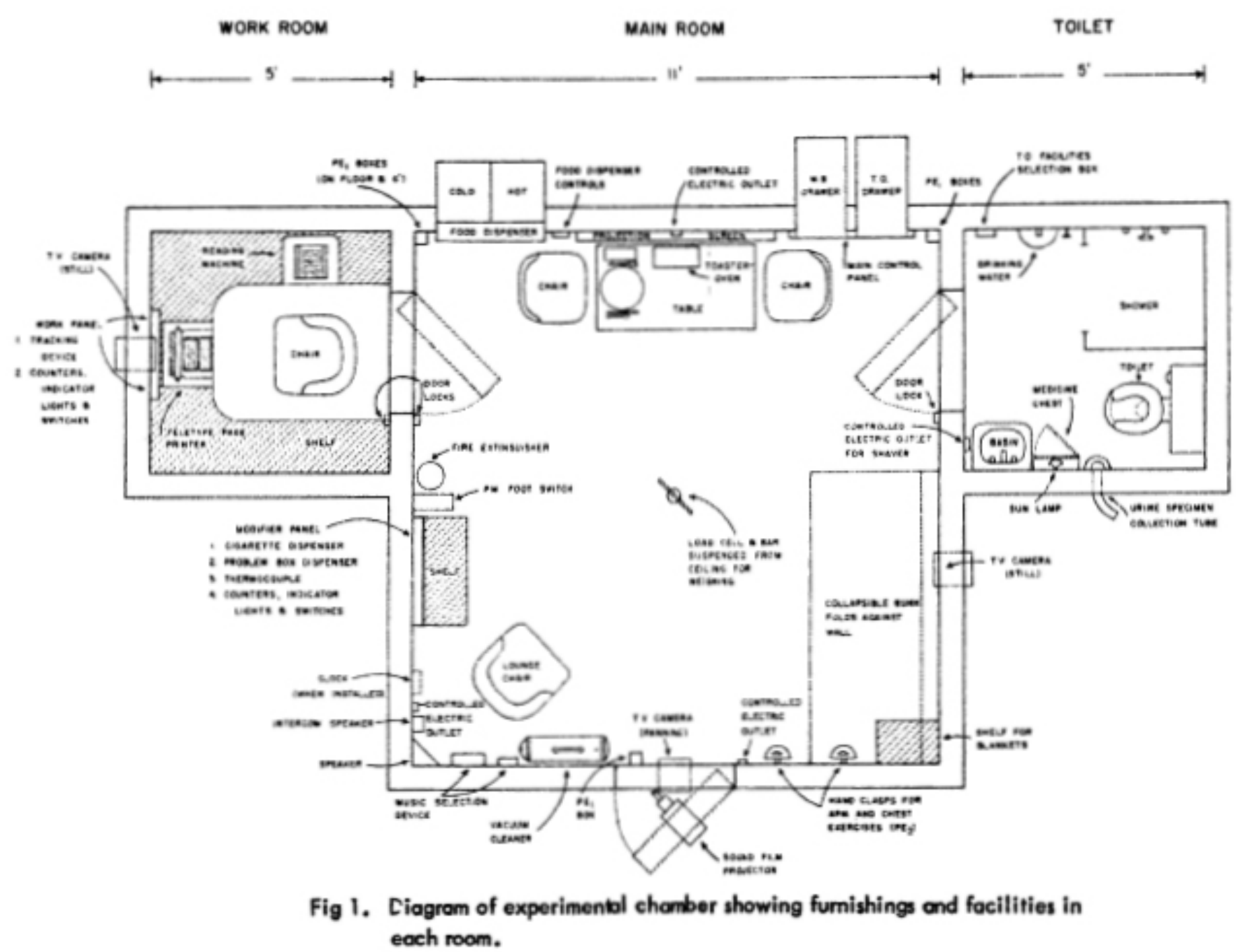

Findley, J.D., Migler, B.M., \& Brady, J.V. (1963). A long-term study of human performance in a continuously programmed experimental environment. Technical Report NASA. p. 12. http://ntrs.nasa.gov/archive/nasa/casi.ntrs.nasa.gov/19640001916 1964001916.pdf 
Extending the Technology to Groups: Systematic Replication
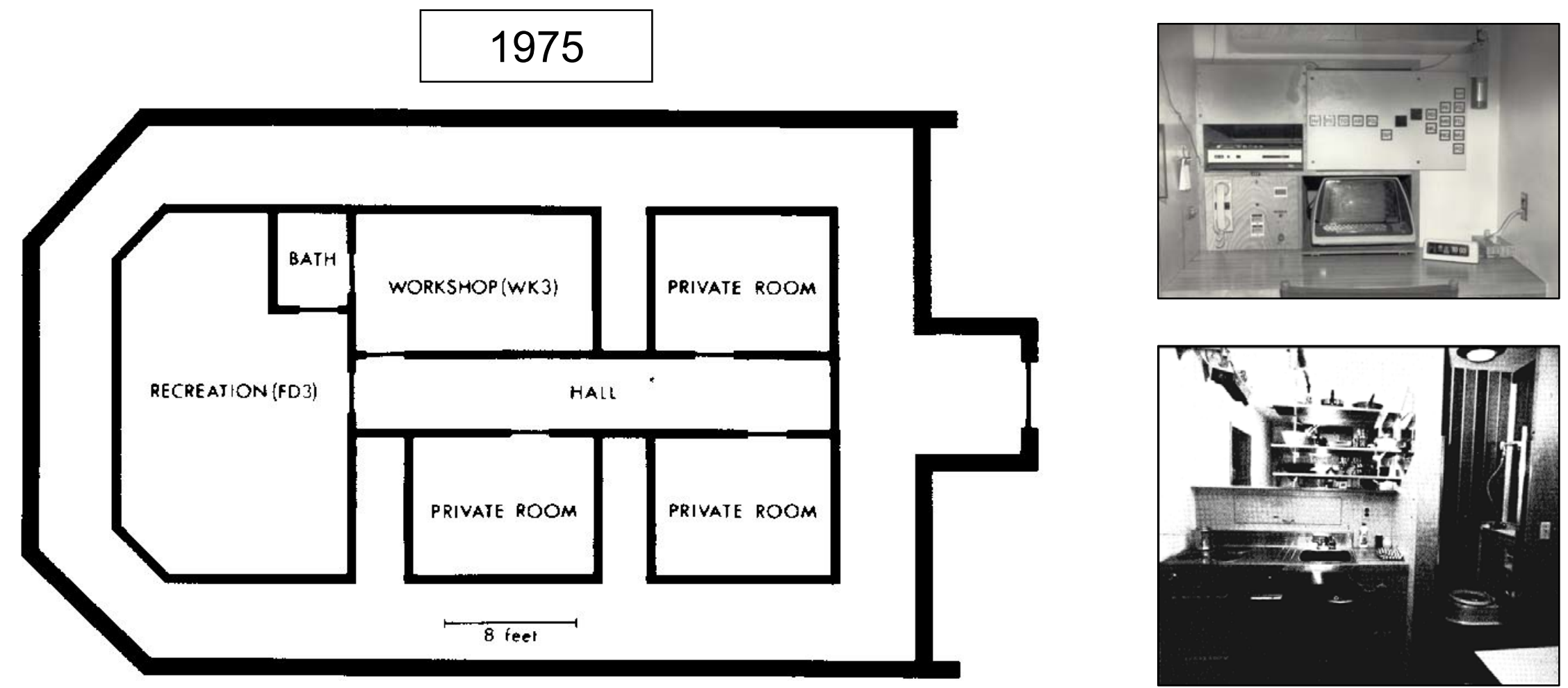

Fig. 1. A schematic diagram of the programmed environment.
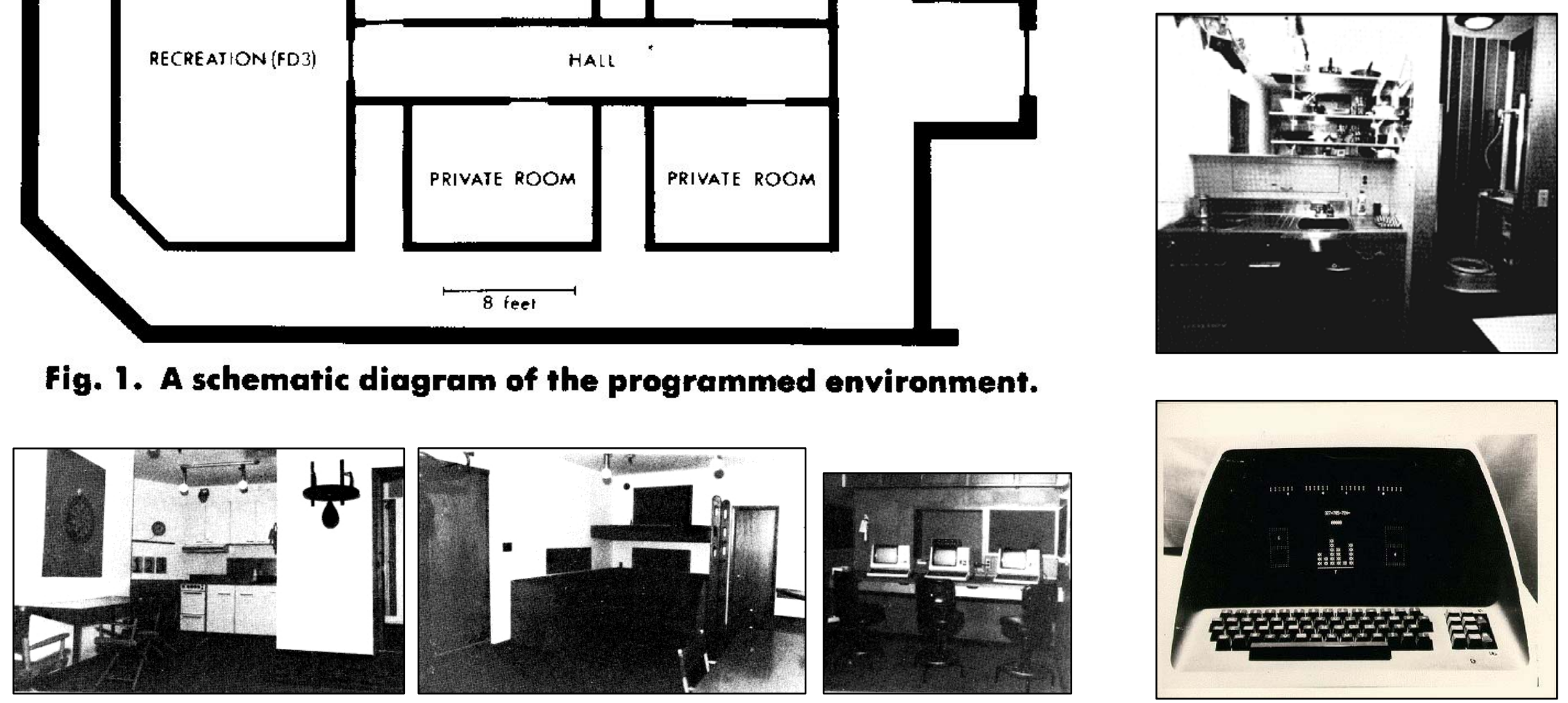


\section{9: MARS 500}
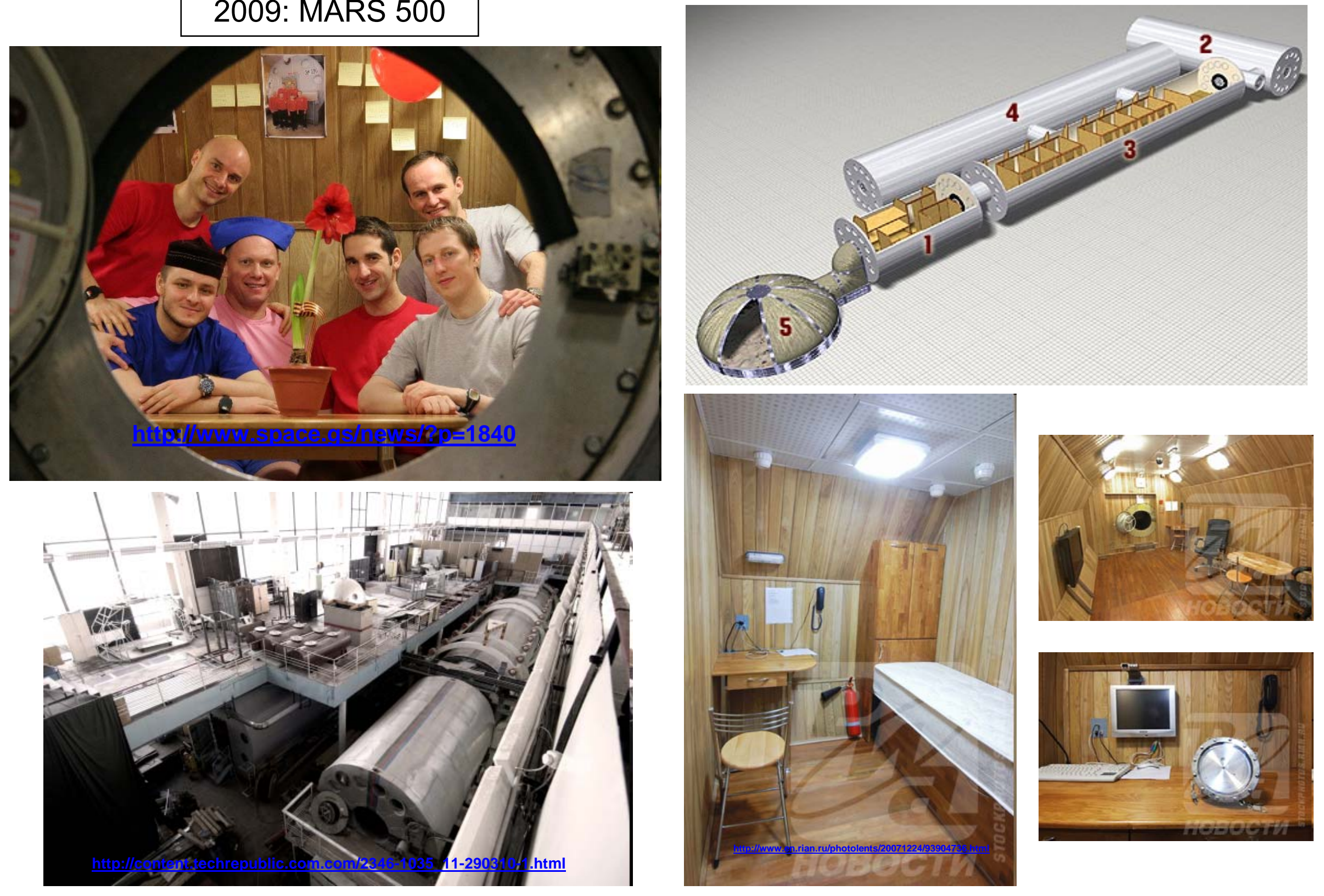
- To Members of the NSBRI Board of Directors, External Advisory Council, Board of Scientific Counselors, User Panel, Industry Forum and Investigator Community:

- 105-Day Mars Simulation: U.S. studies focus on improving work performance

- Release available at: http://www.nsbri.org/NewsPublicOut/Release.epl?r=123

- HOUSTON - (July 13, 2009) - From March 31 to July 14, a sixman international crew called an isolation chamber in Moscow their home. The crew, composed of four Russians and two Europeans, simulated a 105-day Mars mission full of experiments and realistic mission scenarios, including emergency situations and 20-minute communications delays. 


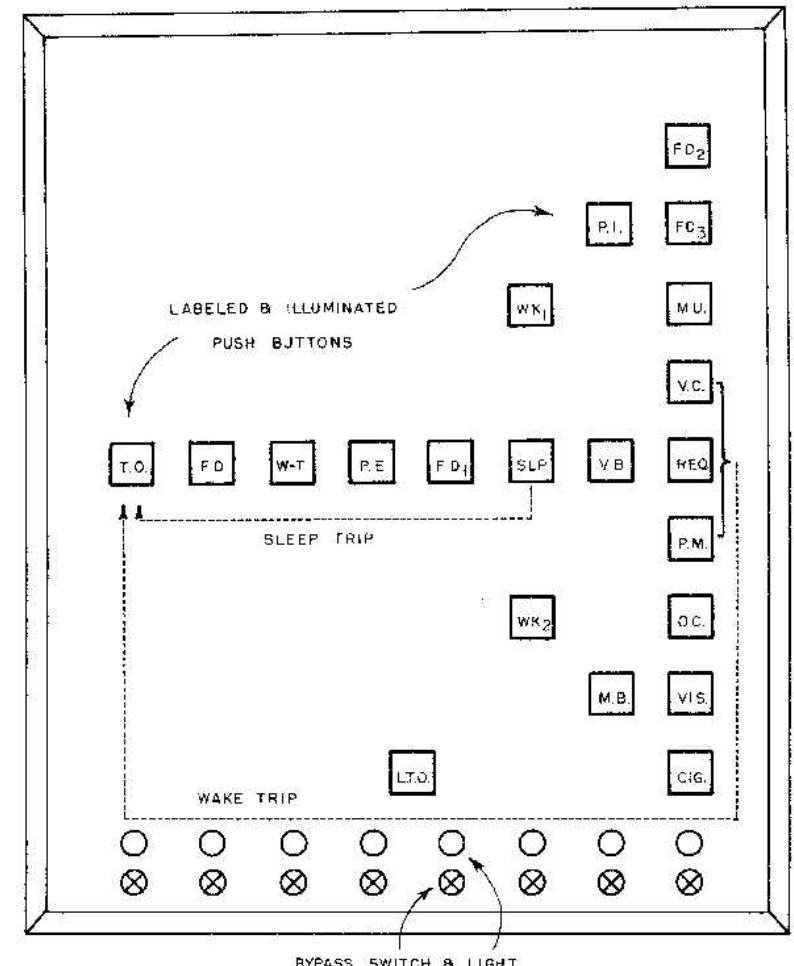

Figure 1. Main control panel containing push buttons that could be illuminated red or green. Each button is labeled with the abbreviations of the activity represented. "Wake Trips" and "Sleep Trips" are indicated by arrows.

\section{Systematic Replication}

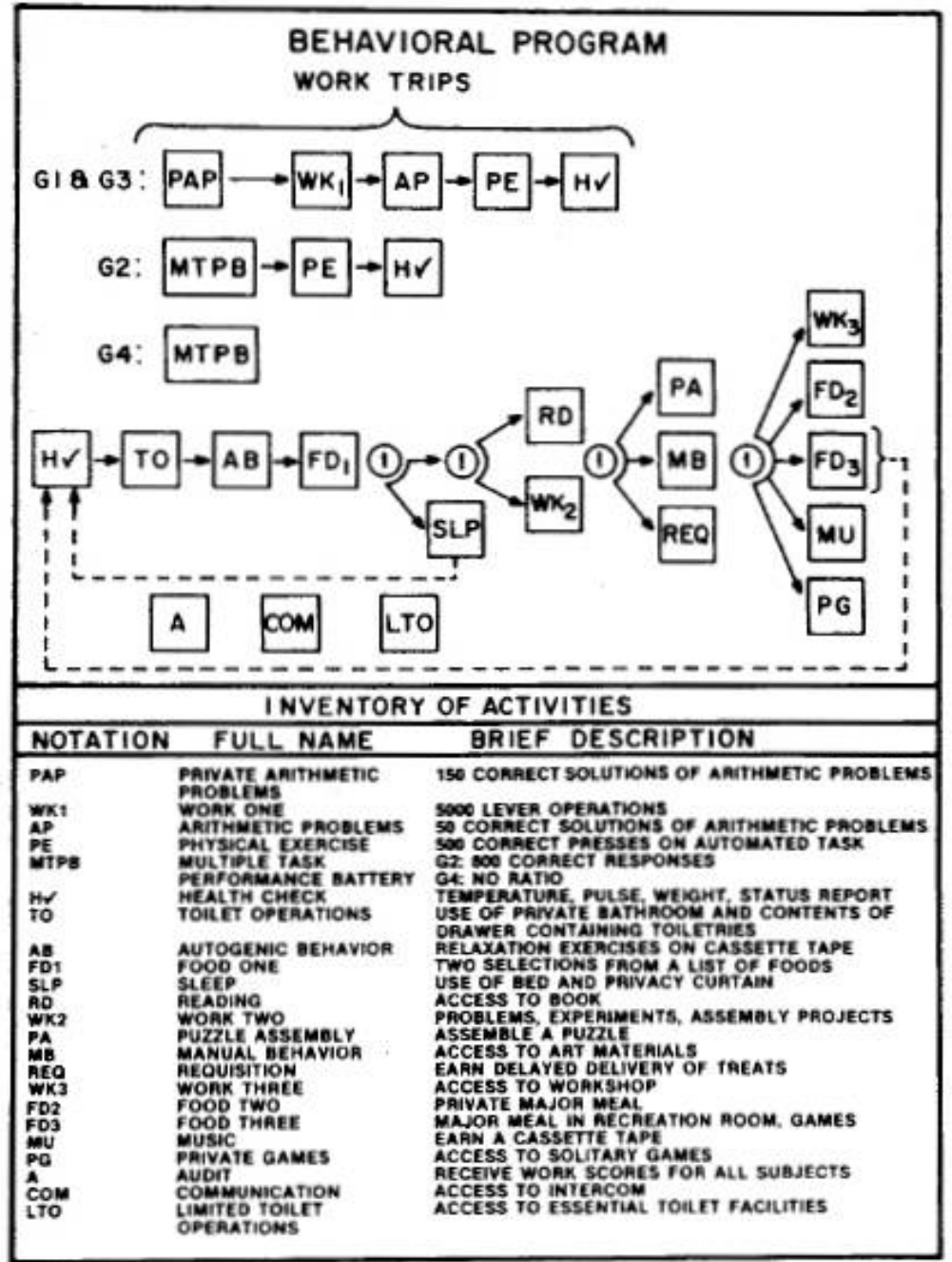

Emurian, H.H. (1988). Programmed environment management of confined microsocieties. Aviation, Space, and Environmental Medicine, 59(10), 976-980. 


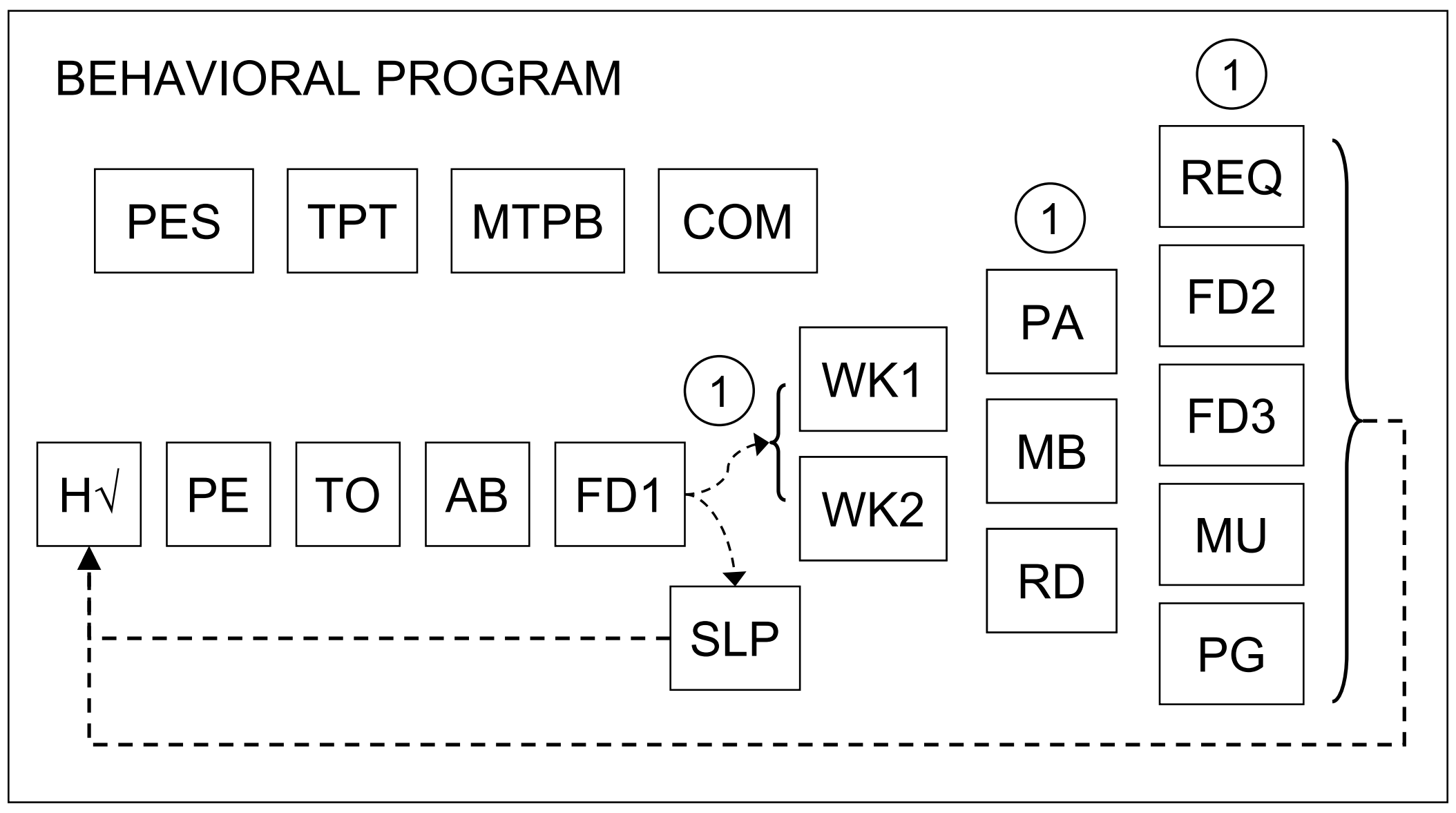




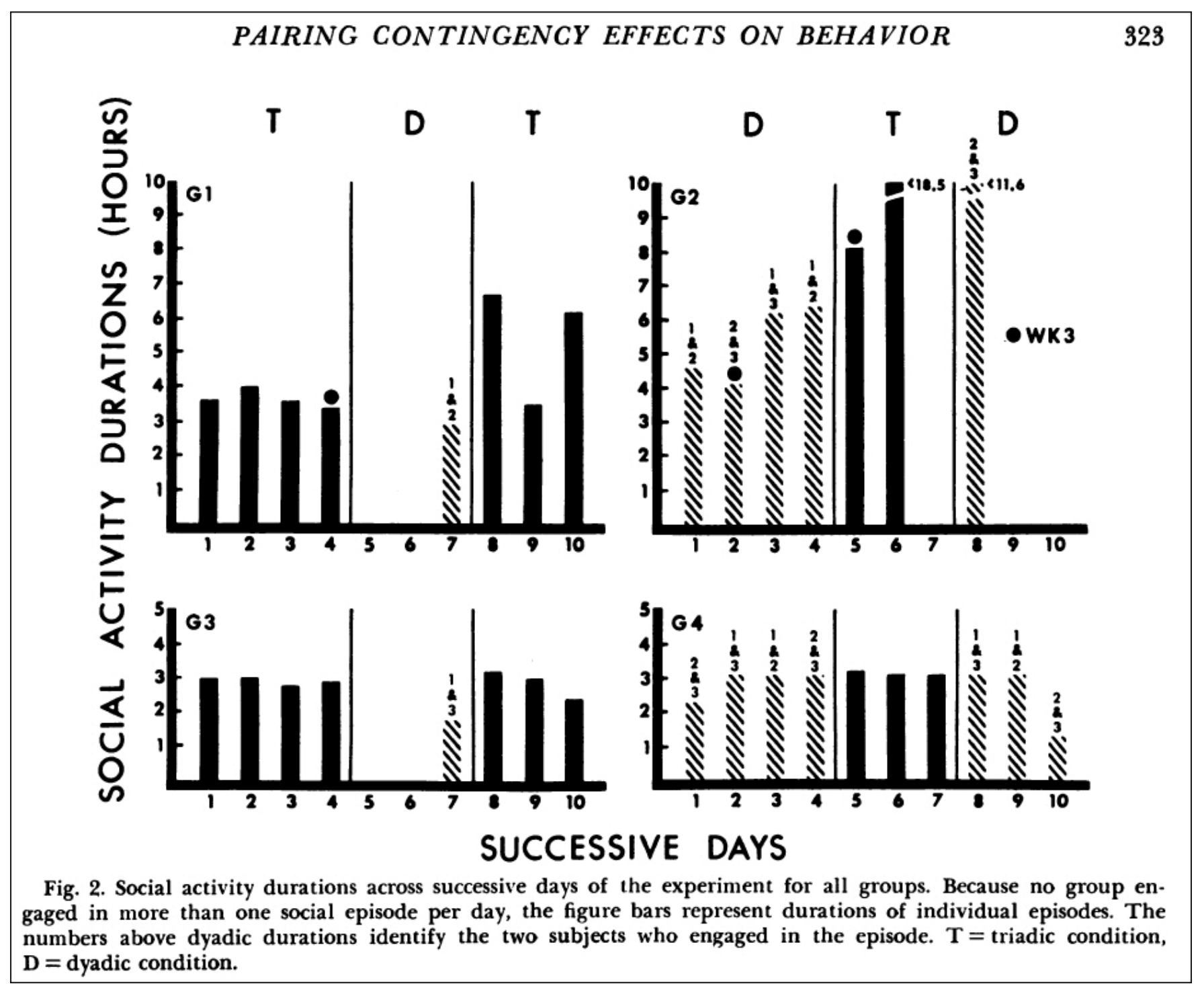

Emurian, H.H., Emurian, C.S., \& Brady, J.V. Effects of a pairing contingency on behavior in a three-person programmed environment. Journal of the Experimental Analysis of Behavior, 1978, 29, 319-329. 


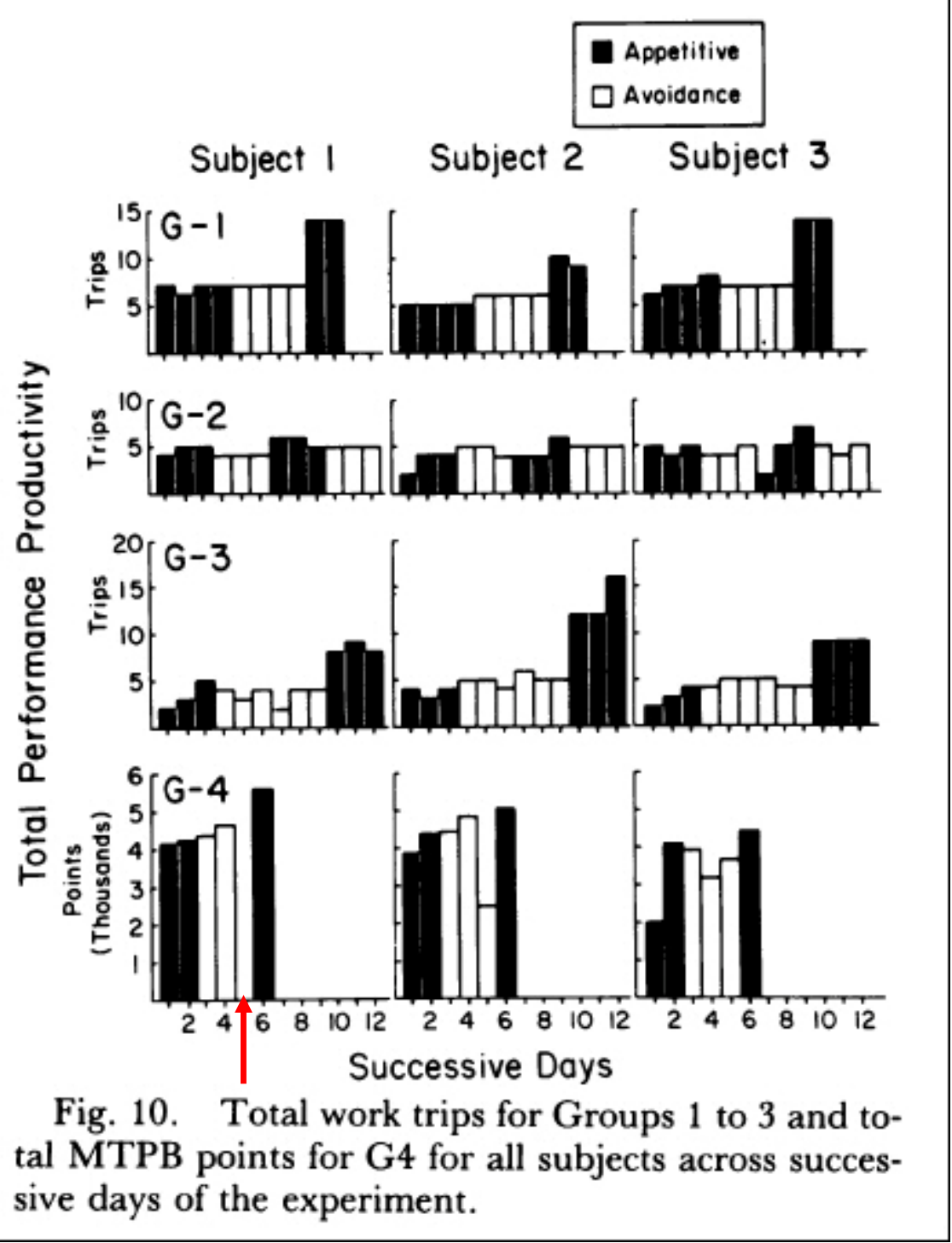

Emurian, H.H., Emurian, C.S., \& Brady, J.V. Positive and negative reinforcement effects on behavior in a threeperson programmed environment. Journal of the Experimental Analysis of Behavior, 1985, 44, 157-174. 


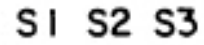 \\ 100}

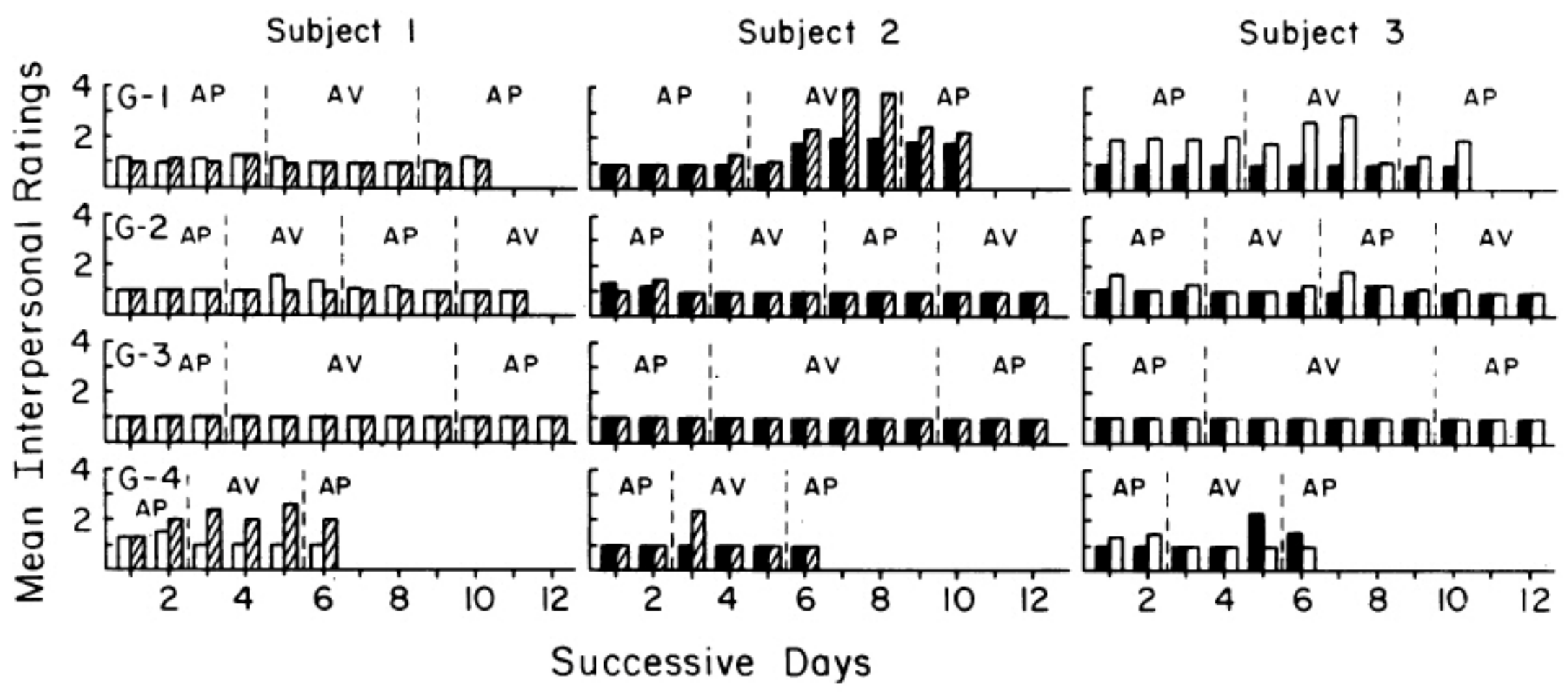

Fig. 5. Mean interpersonal ratings for all subject pairs in each group across successive days of the experiment. $1=$ not at all bothered by a subject, and $4=$ extremely bothered. AP $=$ appetitive condition, and $\mathrm{AV}=$ avoidance condition. 


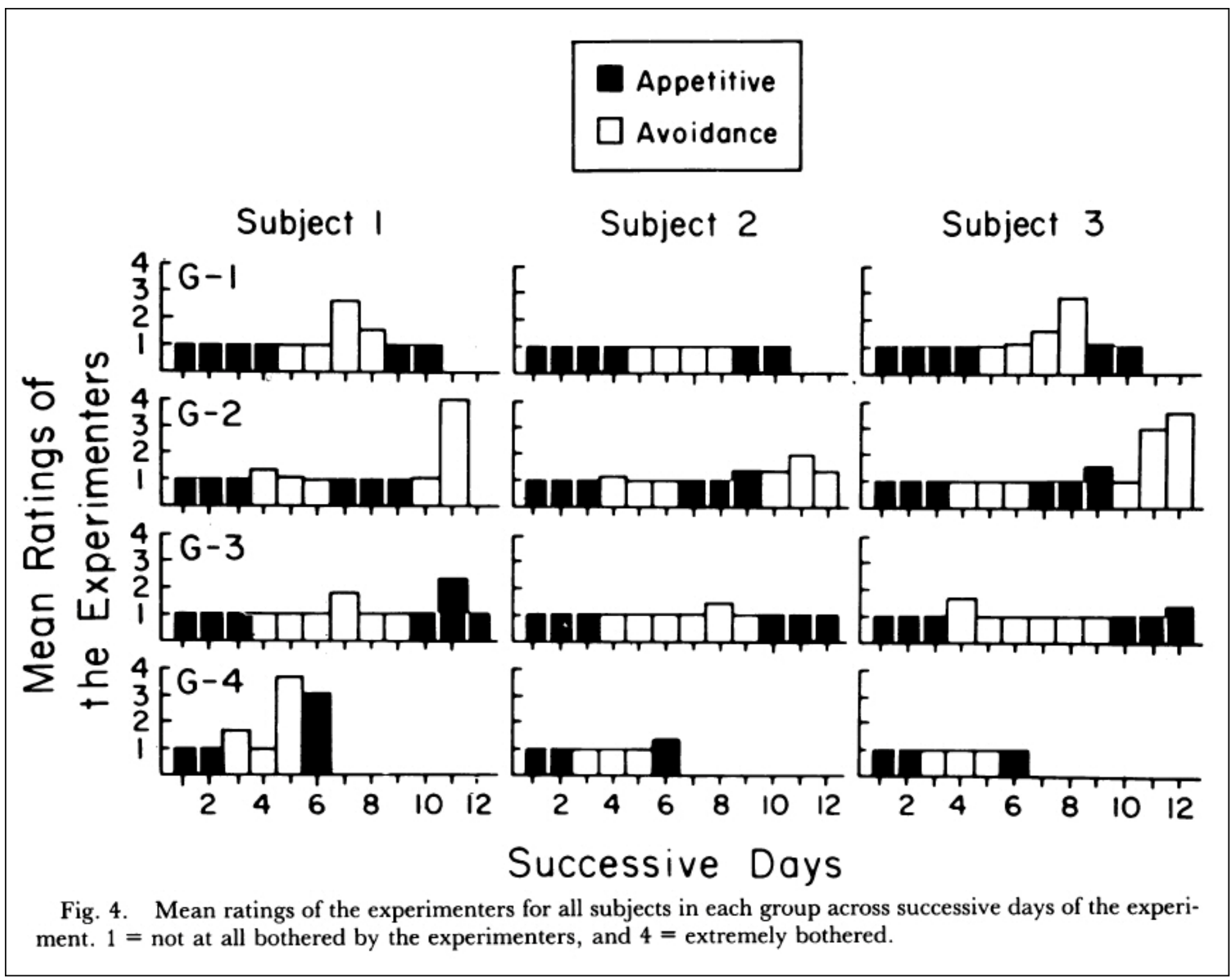




\section{Planetary Exploration Simulation Task (PES)}

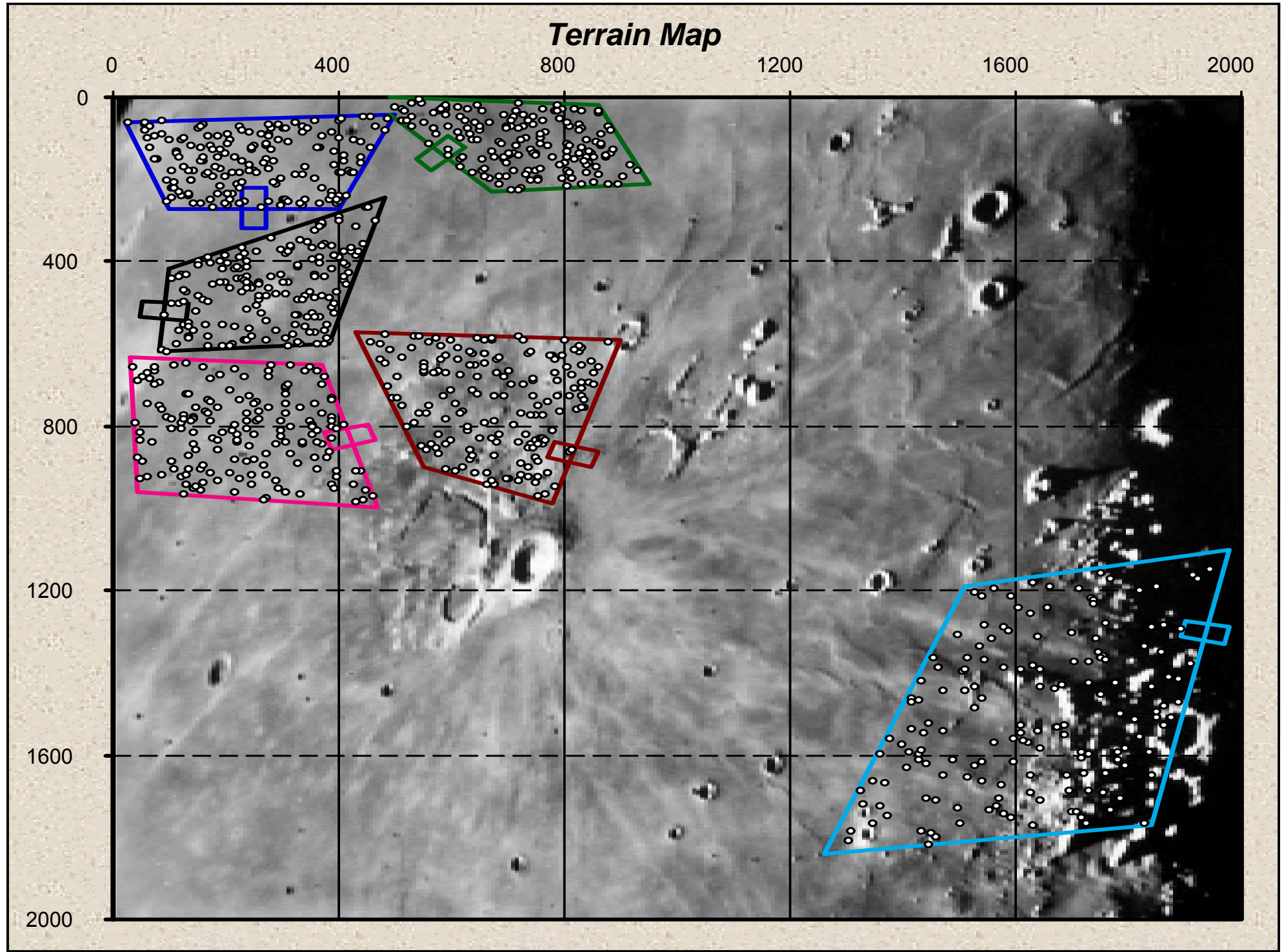




\section{PES}

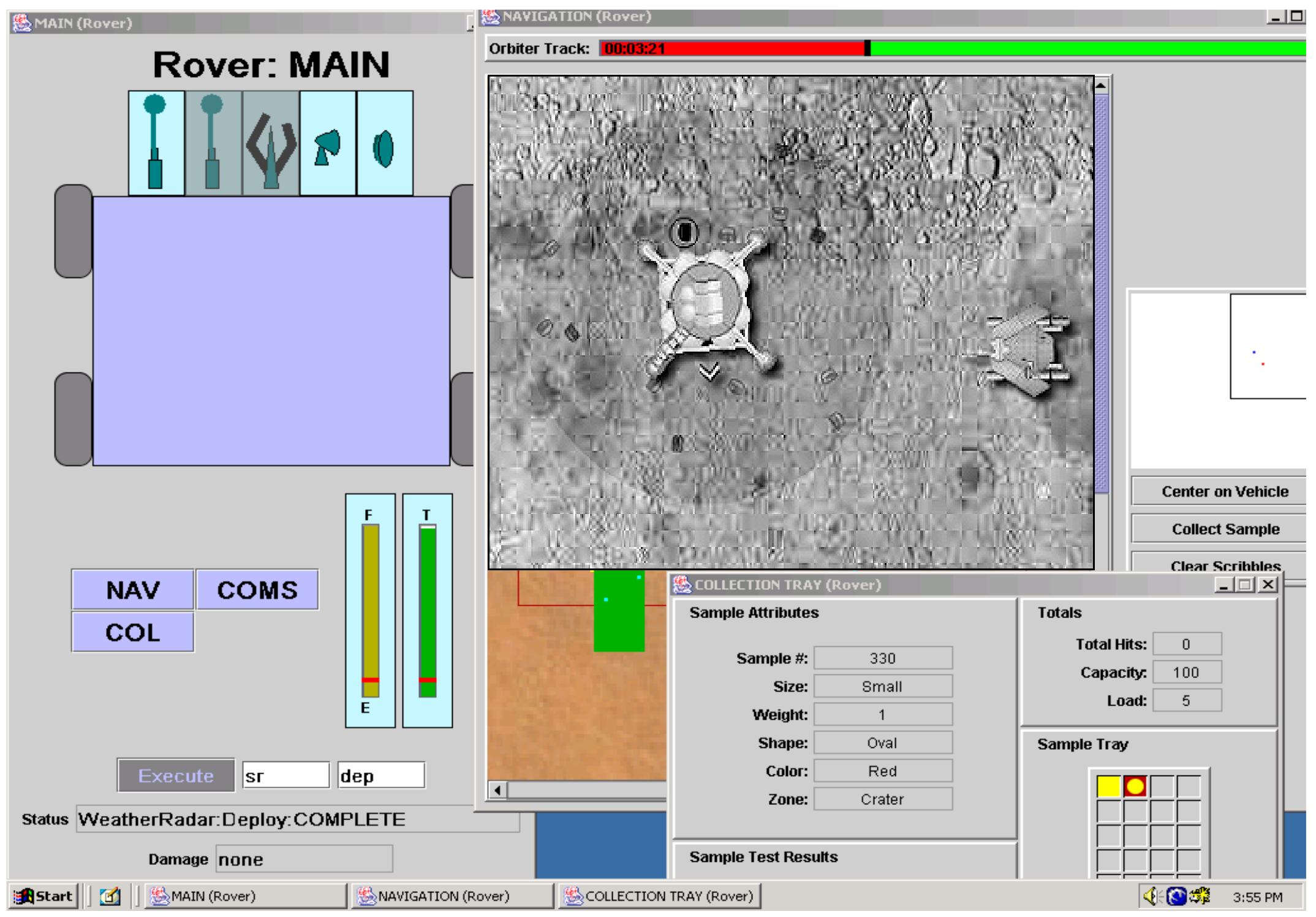




\section{PES}

SNSBRI

Mission Control COM PANEL

\section{$\nabla$ transmit video $\square$ mute headset push to talk}
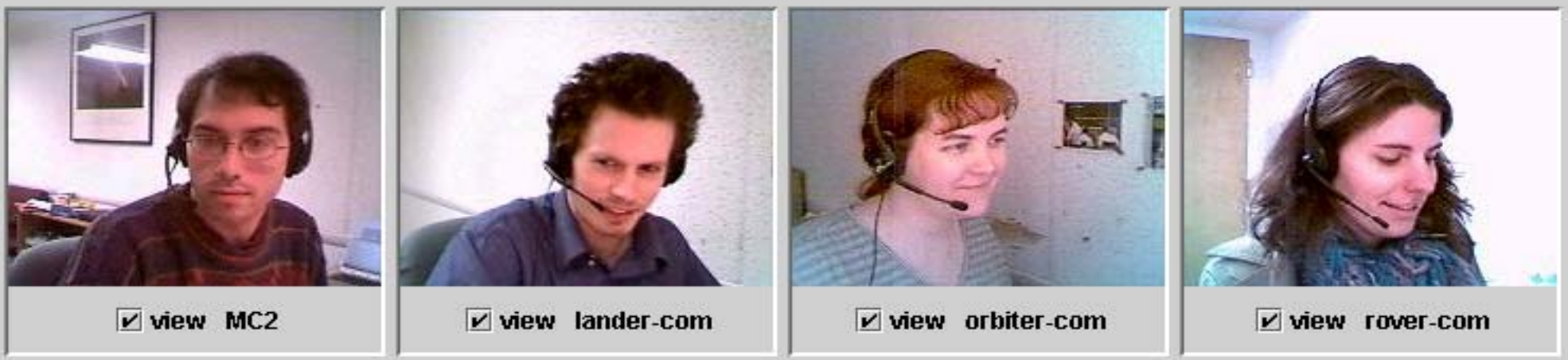

Lander: LOUIELOUIELOUIELOUIELOUIELOUIELOUIELOUIELOUIELOUIELOUIELOUIELOUIELOUIE Rover:

Orbiter: $605=0$

Rover: large/round/yellow $=0$

Orbiter: $613=0$

Rover: med/square/yellow $=0$

Orbiter: $271=0$

Orbiter: $746=0$

Rover: med/round/orange $=0$

Rover: large/rod/orange $=0$ 


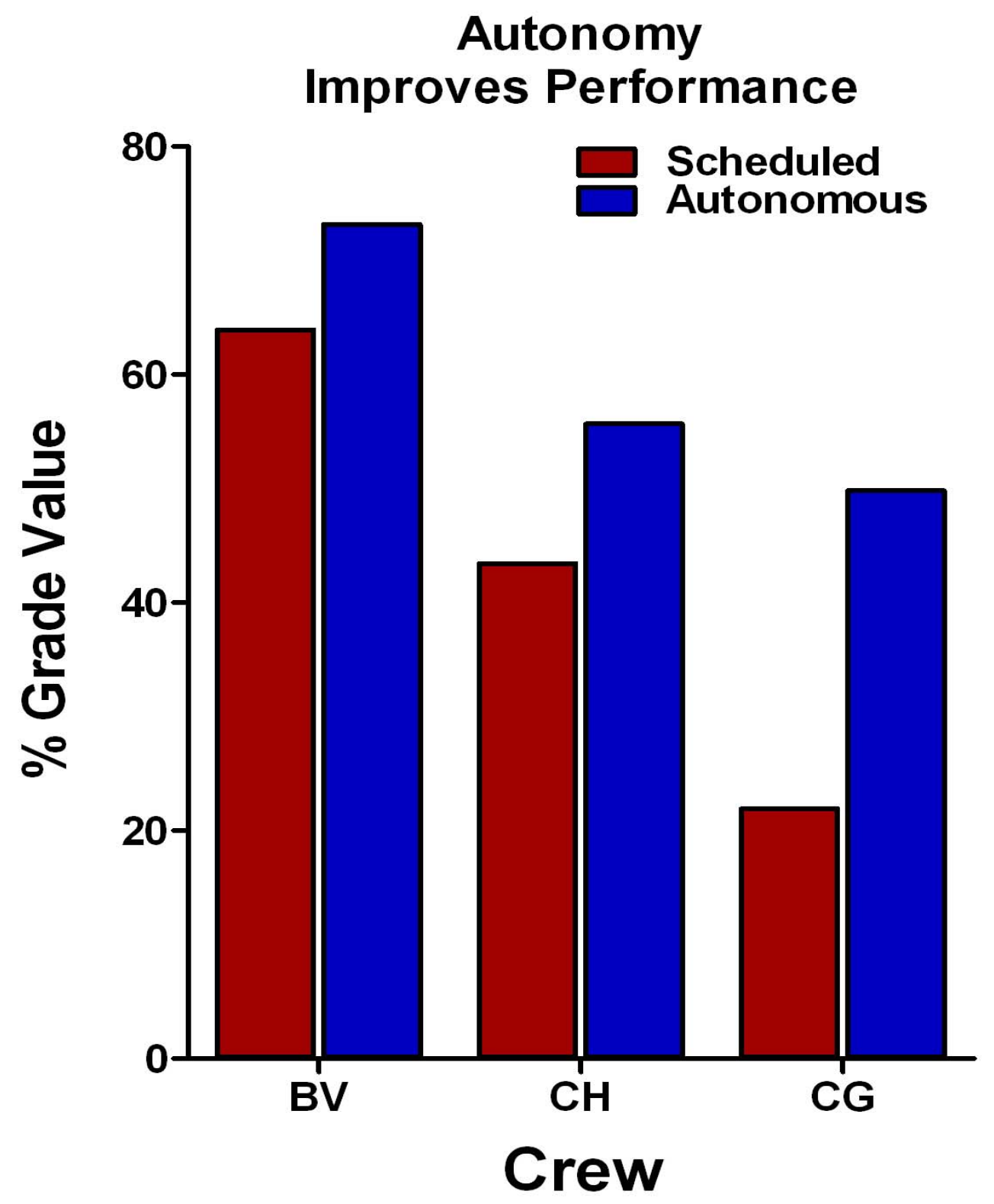




\section{Autonomy Reduces}

Cortisol Reactivty

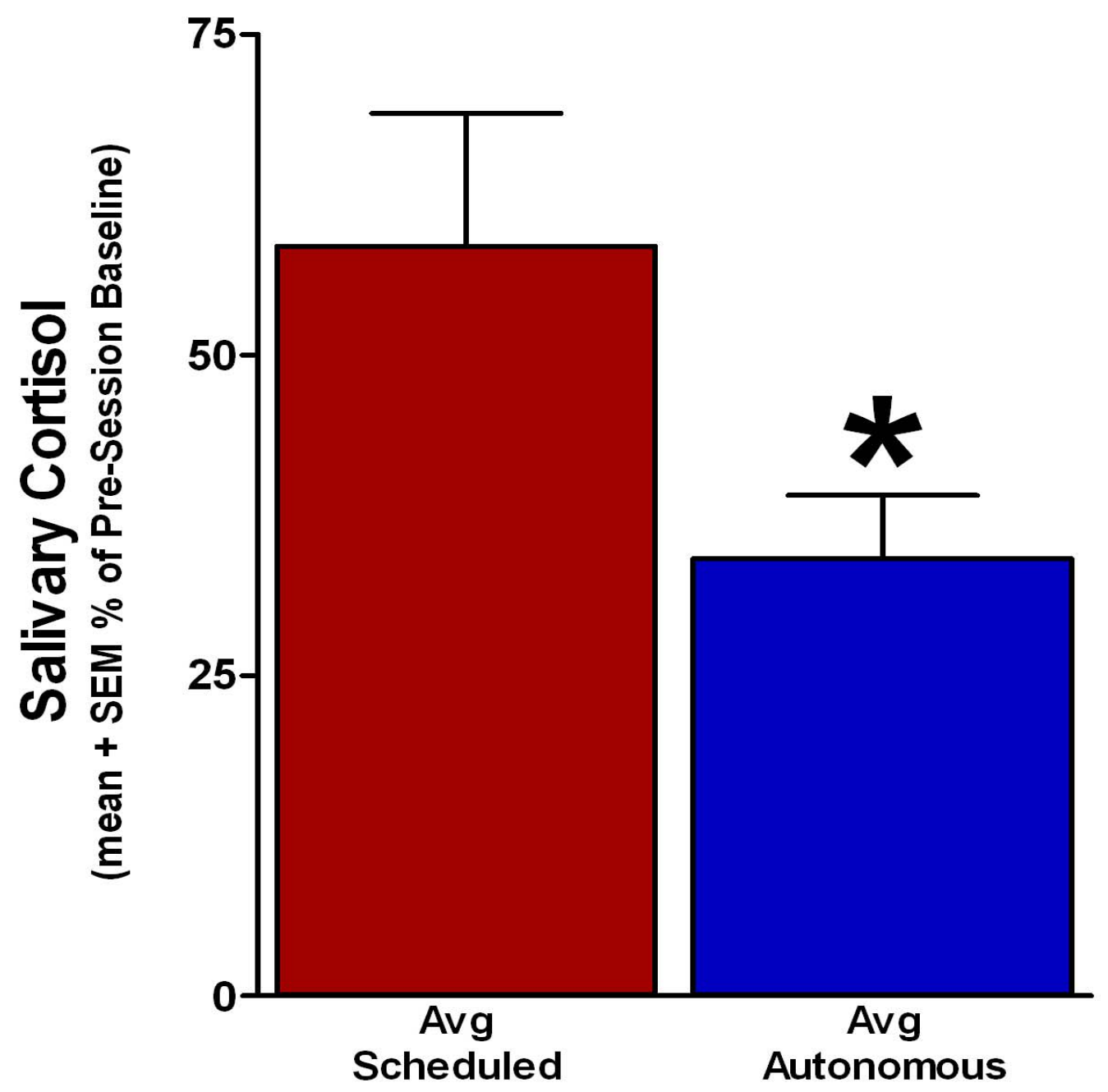




\section{Team Performance Task (TPT)}

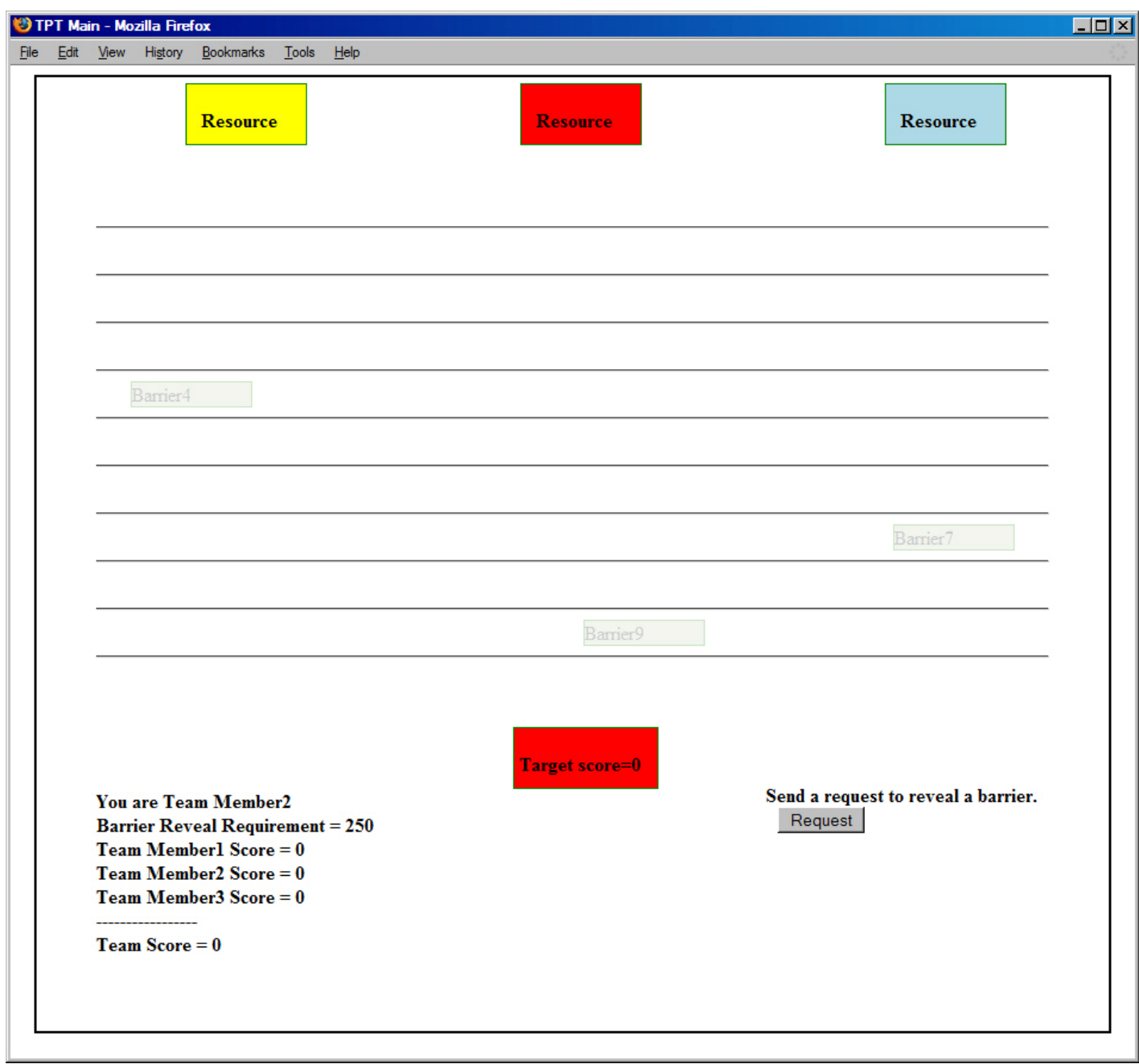




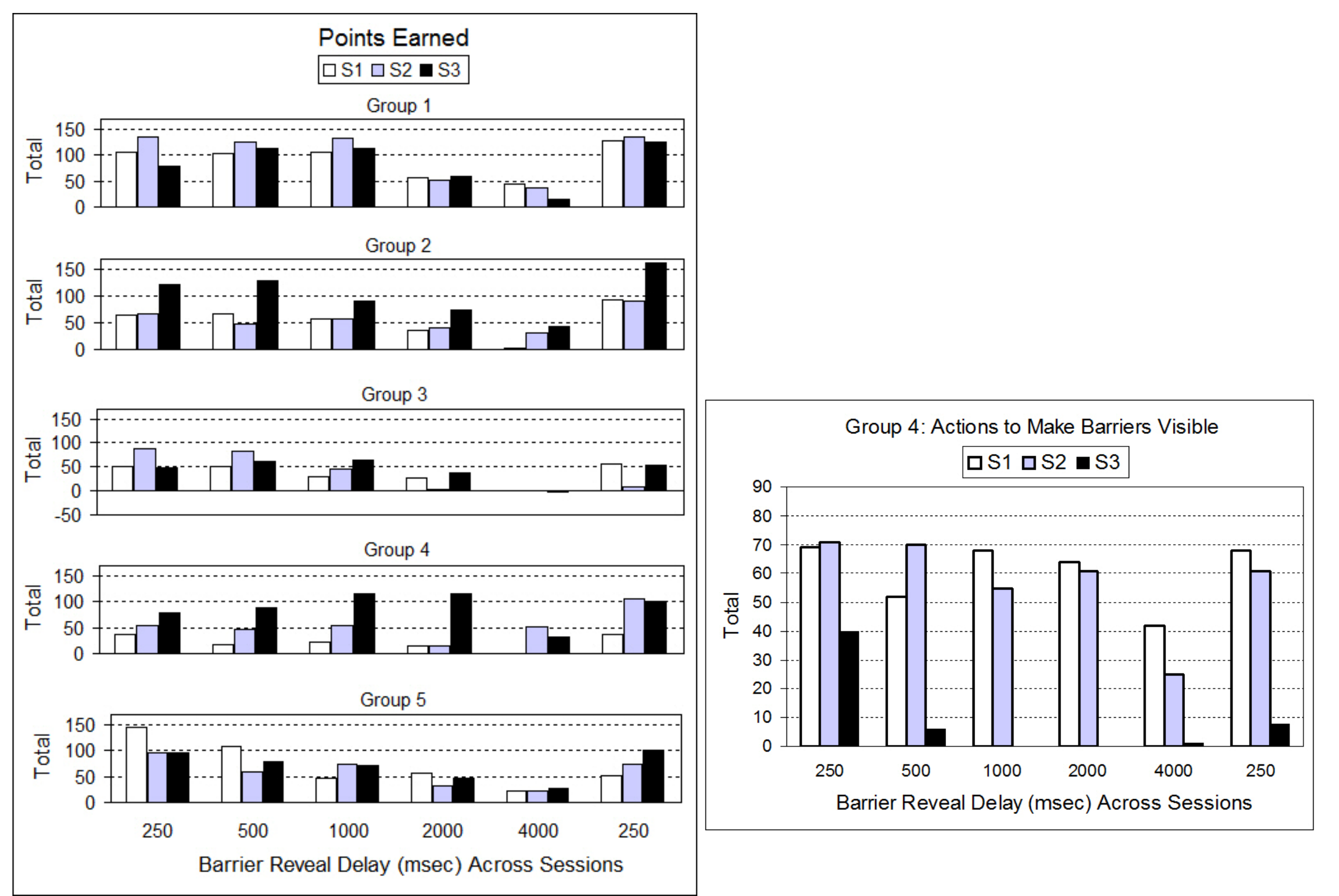


- What are the effects on individual and crew performances and adjustment of social contingencies on high-value activities such as meals and recreation?

- This question addresses such risks to longduration spaceflight as human performance failure due to poor psychosocial adaptation. 
- What are the interactive BP, PES, and TPT markers of impending degradation and loss of mission-critical individual and crew skilled performances, and what interventions will reverse such changes and restore acceptable behavioral health?

- This question addresses such risks as mismatch between crew cognitive capabilities and task demands. 
- In what ways may the behavioral program implement alternative work and rest routines to overcome loss of motivation, social disruption, and degradation in skilled performance?

- What are the differential effects of autonomous and rule-governed access to activity units? 
- In what ways may team-oriented tasks such as the TPT as diagnostic markers of the status of a crew?

- Can such tools be adopted to affirm and maintain social cohesion and role differentiation and identification among crew members and between crew members and mission control? 


\section{Applications: Which Approach?}

\begin{tabular}{|c|c|c|}
\hline \multicolumn{3}{|c|}{$\begin{array}{l}\mathrm{Rg} 0451 \mathrm{u} \\
\text { Prepping Orlans for EVA }\end{array}$} \\
\hline Time & Crew & Ops \\
\hline $06: 00-06: 10$ & CDR,FE-3,FE-5 & Morning inspection \\
\hline 06:00-06:05 & $\mathrm{FE}-4$ & Taking biophosphanat pills \\
\hline 06:00-06:05 & $\mathrm{FE}-1$ & SLEEP - data logging \\
\hline 06:00-06:05 & FE-2 & SLEEP - data logging \\
\hline 06:05-06:10 & FE-1,FE-4 & Morning inspection \\
\hline $06: 05-06: 10$ & FE-2 & Taking biophosphanat pills \\
\hline 06:10-06:40 & $\begin{array}{l}\text { CDR,FE-1,FE-3, } \\
\text { FE-4,FE-5 }\end{array}$ & Post-sleep \\
\hline $06: 10-06: 35$ & FE-2 & Post-sleep \\
\hline 06:35-07:10 & FE-2 & Breakfast \\
\hline 06:40-07:30 & $\begin{array}{l}\text { CDR,FE-1,FE-3, } \\
\text { FE-4,FE-5 }\end{array}$ & Breakfast \\
\hline 07:10-07:25 & $\mathrm{FE}-2$ & Private Psych Conference (Ku+S-band) \\
\hline 07:25-07:30 & FE-2 & Breakfast \\
\hline 07:30-07:40 & FE-4 & PHS $\mathrm{h} / \mathrm{w}$ installation \\
\hline 07:30-07:40 & $\begin{array}{l}\text { CDR,FE-1,FE-2, } \\
\text { FE-3,FE-5 }\end{array}$ & Work prep \\
\hline 07:40-08:05 & . & DPC (S-band) \\
\hline 08:05-08:15 & $\begin{array}{l}\text { CDR,FE-1, } \\
\text { FE-4,FE-5 }\end{array}$ & Work prep \\
\hline 08:05-08:45 & FE-3 & Taking photos of docking probe traces on docking cone (ACП-Б) of FGB \\
\hline 08:05-09:20 & FE-2 & PE CEVIS \\
\hline 08:15-08:45 & $\begin{array}{l}\text { FE-4, } \\
\text { FE-5(--мощь) }\end{array}$ & Periodic health check \\
\hline
\end{tabular}

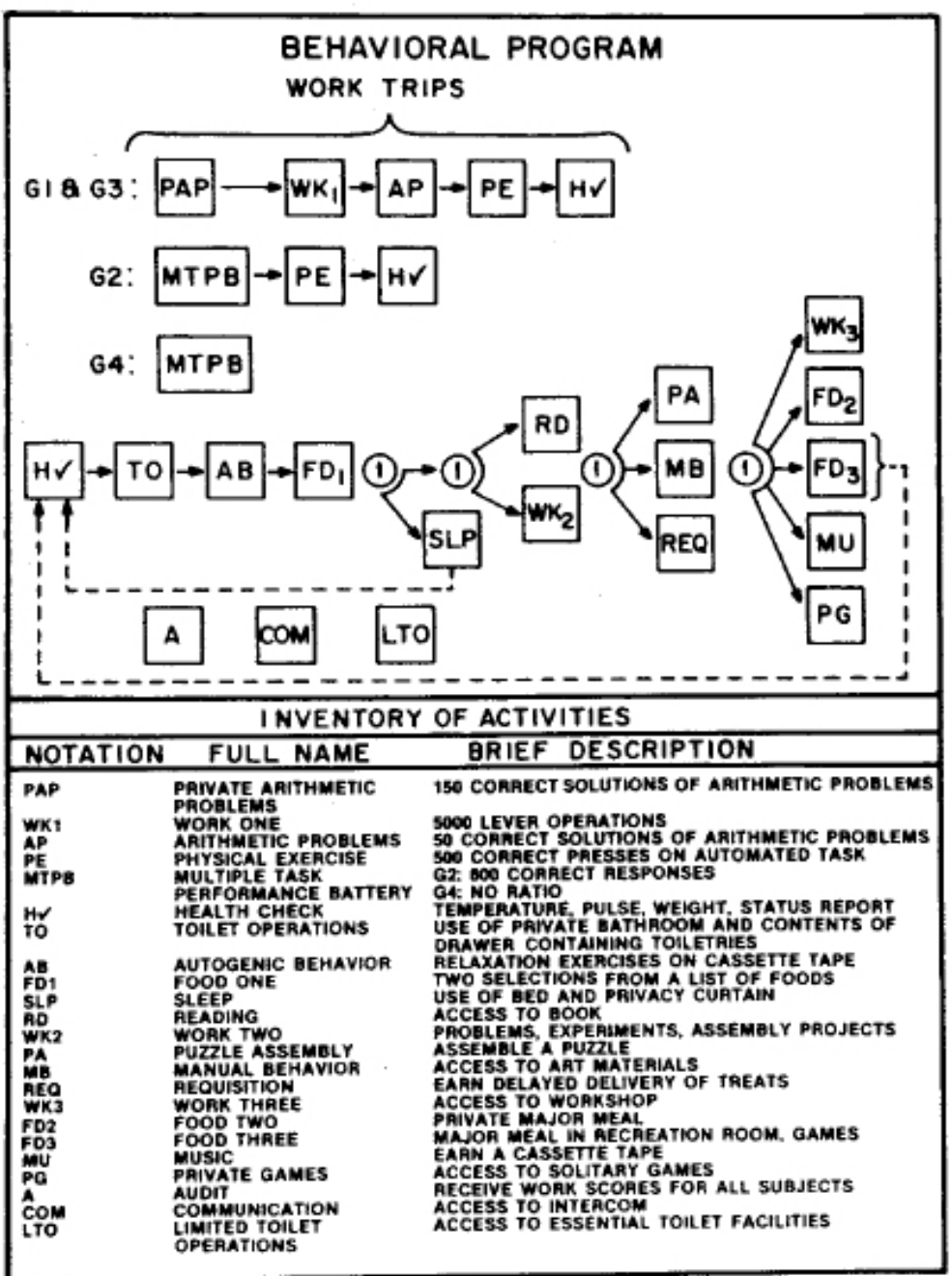




\section{Both approaches have value at different occasions in a mission to Mars.}

\begin{tabular}{|c|c|c|}
\hline \multicolumn{3}{|c|}{$\begin{array}{l}\mathrm{Rg} 0451 \mathrm{u} \\
\text { Prepping Orlans for EVA }\end{array}$} \\
\hline Time & Crew & Ops \\
\hline $06: 00-06: 10$ & CDR,FE-3,FE-5 & Morning inspection \\
\hline 06:00-06:05 & $\mathrm{FE}-4$ & Taking biophosphanat pills \\
\hline 06:00-06:05 & $\mathrm{FE}-1$ & SLEEP - data logging \\
\hline 06:00-06:05 & FE-2 & SLEEP - data logging \\
\hline 06:05-06:10 & FE-1,FE-4 & Morning inspection \\
\hline $06: 05-06: 10$ & FE-2 & Taking biophosphanat pills \\
\hline 06:10-06:40 & $\begin{array}{l}\text { CDR,FE-1,FE-3, } \\
\text { FE-4,FE-5 }\end{array}$ & Post-sleep \\
\hline $06: 10-06: 35$ & FE-2 & Post-sleep \\
\hline 06:35-07:10 & FE-2 & Breakfast \\
\hline 06:40-07:30 & $\begin{array}{l}\text { CDR,FE-1,FE-3, } \\
\text { FE-4,FE-5 }\end{array}$ & Breakfast \\
\hline 07:10-07:25 & $\mathrm{FE}-2$ & Private Psych Conference (Ku+S-band) \\
\hline 07:25-07:30 & FE-2 & Breakfast \\
\hline 07:30-07:40 & FE-4 & PHS $\mathrm{h} / \mathrm{w}$ installation \\
\hline 07:30-07:40 & $\begin{array}{l}\text { CDR,FE-1,FE-2, } \\
\text { FE-3,FE-5 }\end{array}$ & Work prep \\
\hline 07:40-08:05 & . & DPC (S-band) \\
\hline 08:05-08:15 & $\begin{array}{l}\text { CDR,FE-1, } \\
\text { FE-4,FE-5 }\end{array}$ & Work prep \\
\hline 08:05-08:45 & FE-3 & Taking photos of docking probe traces on docking cone (ACП-Б) of FGB \\
\hline 08:05-09:20 & FE-2 & PE CEVIS \\
\hline 08:15-08:45 & $\begin{array}{l}\text { FE-4, } \\
\text { FE-5(--мощь) }\end{array}$ & Periodic health check \\
\hline
\end{tabular}

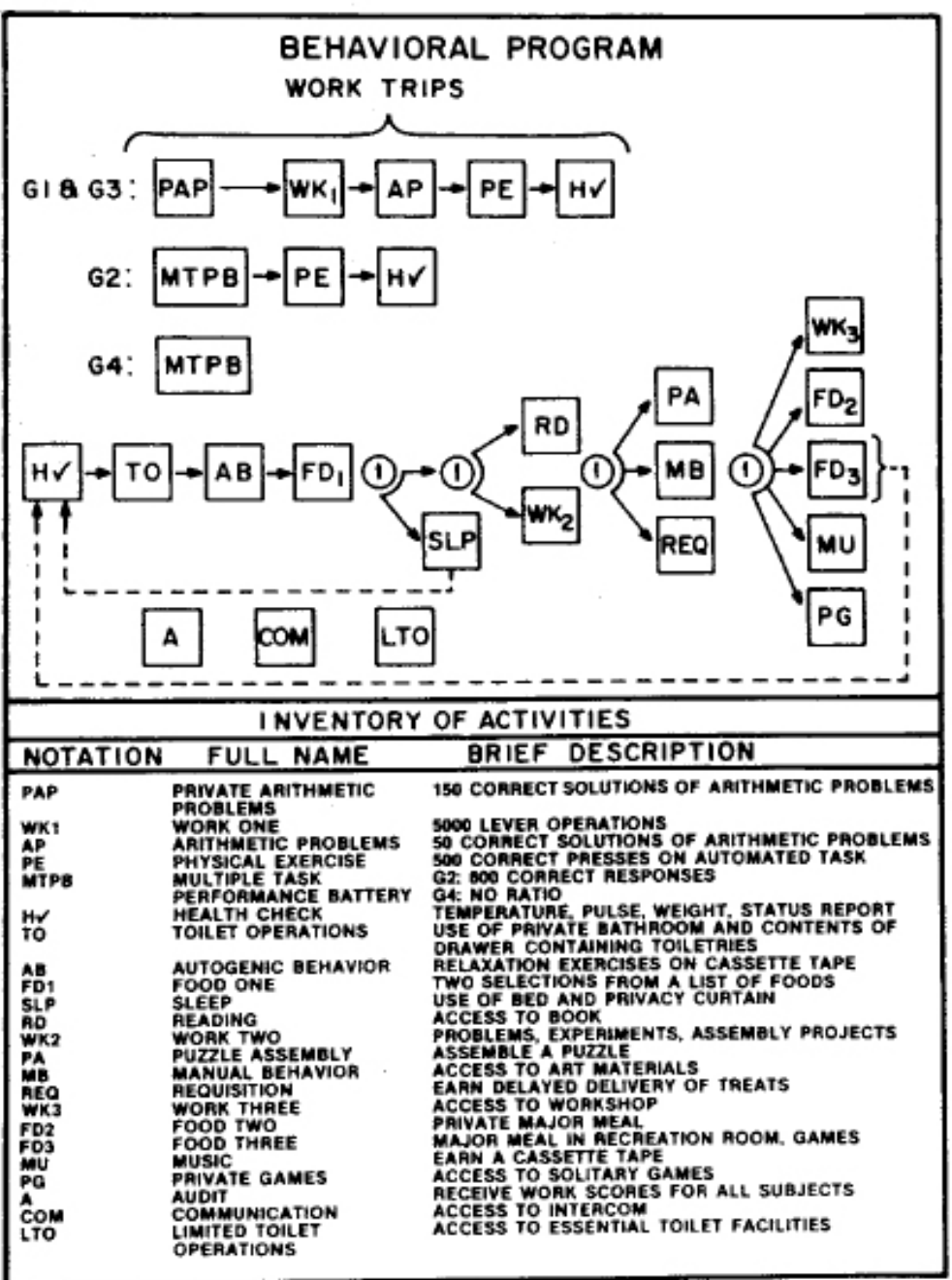




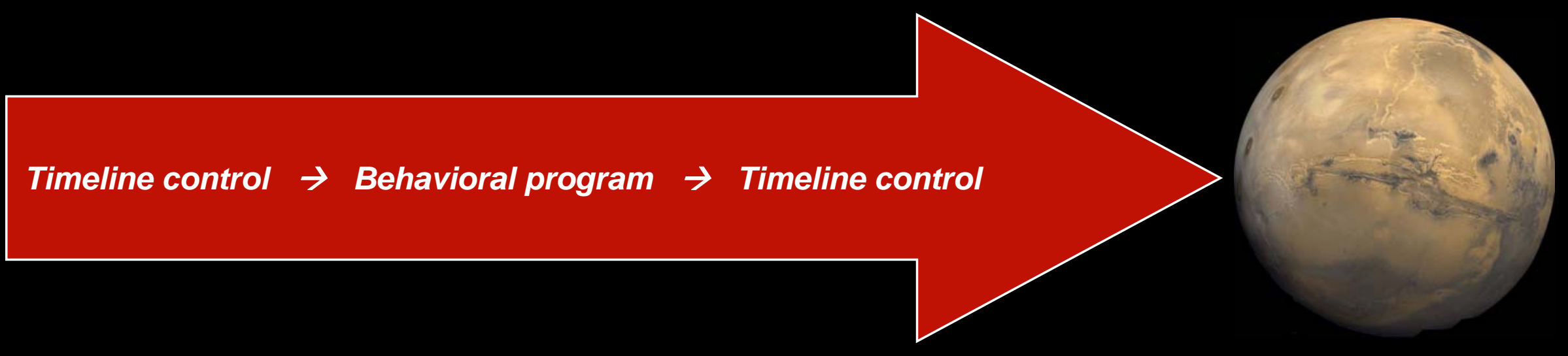


- Develop evidenced-based principles.

- Behavioral systems management.

- Long-duration simulations and evaluations of this approach are indicated. 
- The end result, as stated within NASA's Behavioral Health \& Performance Element, is to optimize the adaptation of the individual and crew to the space environment and maintain motivation, morale, productivity, cohesion, and communication.

http://humanresearch.jsc.nasa.gov/elements/bhp.asp 
Thank you!

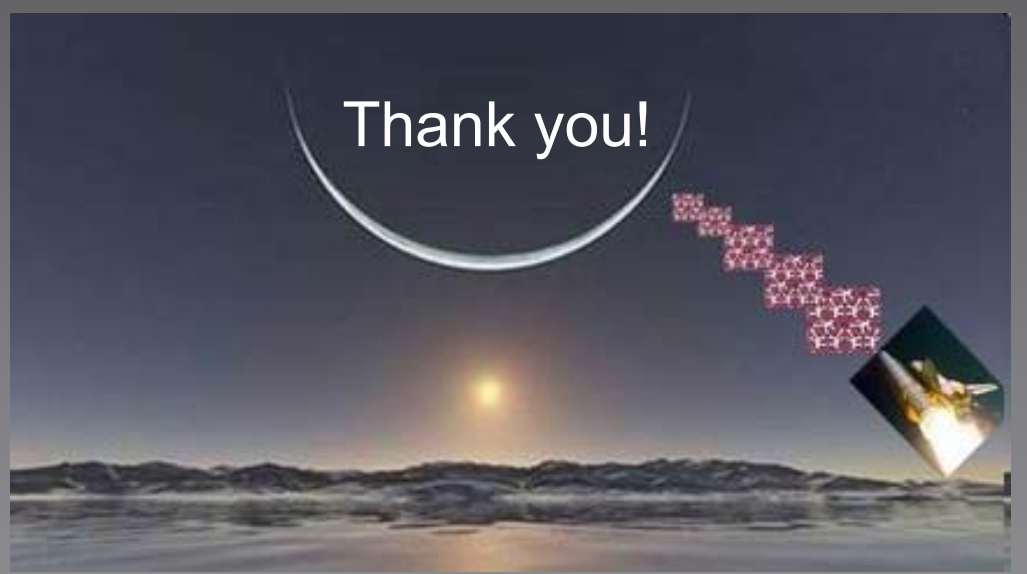

